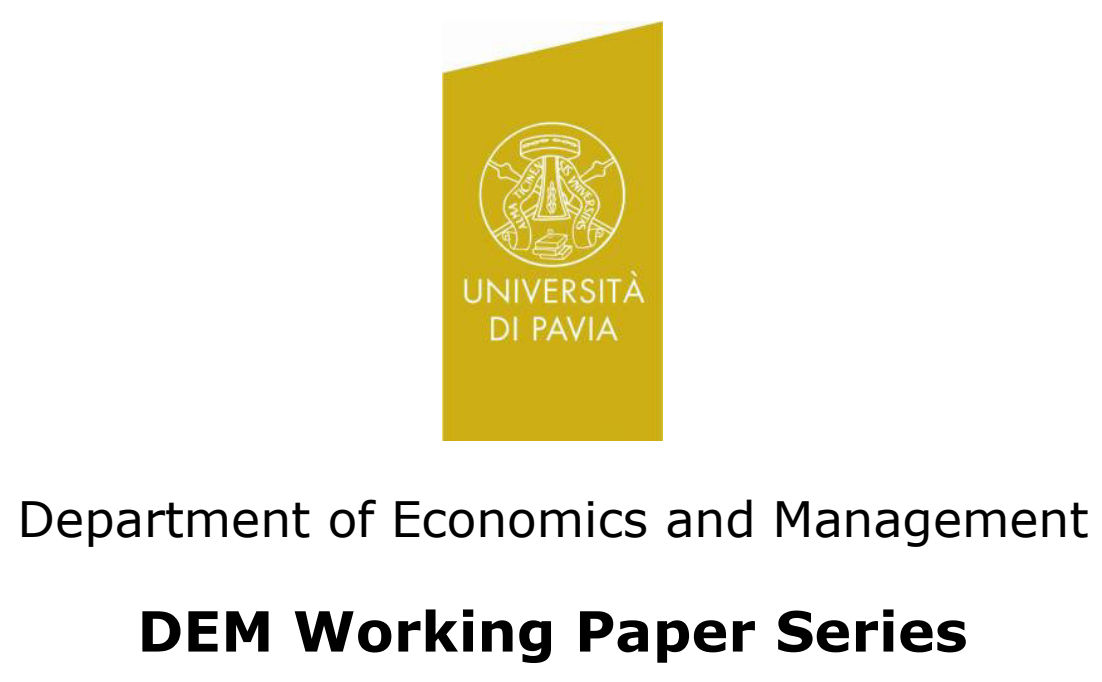

\title{
The Impact of Low-Skilled Immigration on Female Labour Supply
}

\author{
Emanuele Forlani \\ (Università di Pavia) \\ Elisabetta Lodigiani \\ (Università di Venezia - Ca' Foscari) \\ Concetta Mendolicchio \\ (Institute for Employment Research, IAB)
}

\# 58 (06-13)

Via San Felice, 5

I-27100 Pavia

http://epmq.unipv.eu/site/home.html 


\title{
The Impact of Low-Skilled Immigration on Female Labour Supply*
}

\author{
Emanuele Forlani $^{\mathrm{a}, \mathrm{d}}$, Elisabetta Lodigiani ${ }^{\mathrm{b}, \mathrm{d}}$, and Concetta Mendolicchio ${ }^{\mathrm{c}}$ \\ ${ }^{a}$ Università degli Studi di Pavia \\ ${ }^{\mathrm{b}}$ Università di Venezia - Ca' Foscari \\ ${ }^{\mathrm{c}}$ Institute for Employment Research (IAB) \\ d Centro Studi Luca d'Agliano
}

\begin{abstract}
This paper contributes to the literature on the impact of immigrants on native female labour supply. By segmenting the market by educational levels, we are able to investigate which native-born women are more affected by an increase of low-skilled immigrants working in the household service sector. We present a model of individual choice with home production and, using an harmonized dataset (CNEF), we test its main predictions. Our sample includes countries implementing different family policies. Our results suggest that the share of immigrants working in services in a given local labour market is positively associated with the probability of native-born women to increase their labour supply at the intensive margin (number of hours worked per week), if skilled, and at the extensive margin (participation decision), if unskilled. Moreover, they show that these effects are larger in countries with less family-supportive policies.
\end{abstract}

JEL Classification: J22, J61

Keywords: Female labour participation, international migration, family policy

${ }^{*}$ We acknowledge the financial support of the Institute for Employment Research (IAB). We would like to acknowledge for the data contribution the following institutes: Australian Bureau of Statistics, HILDA, SHP, Swiss Federal Statistical Office, SOEP, BHPS, Office for National Statistics (UK), PSID, IPUMS, and Bertelsmann Foundation. Emanuele Forlani acknowledges the financial support from Cariplo Foundation International Recruitment Call: The internationalization of Italian firms: the role of intangibles, managerial resources, and corporate governance. We wish to thank participants at the Lunch Seminar, IAB, Nürnberg, and at the NORFACE Migration Conference, UCL, London, for their helpful comments. The responsibility for any remaining mistakes is our own. 


\section{Introduction}

International migration may alter significantly the labour market conditions in the destination countries. As a first order effect, it may change the prevailing wage rates in the sectors where large number of migrants look for a job. In particular, unskilled migrants represent a significant fraction of employed in sectors that provide services to households. Several recent studies (Barone and Mocetti, 2011; Cortés and Tessada, 2011; Farré et al., 2011) show that, in various countries, low-skilled immigrants have contributed to a decrease in the prices of household services where they specialize, such as housekeeping, childbearing, or caring of elderly. These services are, typically, a substitute for time consuming activities carried out within the family and, mostly, by women. This is especially true in countries with weak public policies (such as nursery, care for elderly and the like). Since large immigration reduces the relative prices of the substitute services (Cortés, 2008), it may have a second order effect on the labour supply of native women, increasing their labour supply at both the intensive and the extensive margin. Intuitively, this effect should be larger for high skill, high wage native women.

This paper aims to study the impact that unskilled migrants in household service sector have on native, female labour supply for a group of developed countries, which differ in terms of family social policies, considering both their effects on labour market participation and on the number of hours actually worked.

The previous studies closely related to our, focus on a single country, usually one with weak family-supporting social policies. In particular, for USA, Cortés and Tessada (2011) find that the labour supply of high-skilled US women is positively affected by low-skilled immigration, at the intensive margin. For Spain, Farré et al. (2011) show that the positive effect of female immigration on the labour supply of Spanish women depends on educational level and family responsibilities of natives. For Italy, Barone and Mocetti (2011) study how the inflow of female immigrants affects the labour supply of both high-skilled and low-skilled Italian women. As in previous papers, they find a positive impact only on the amount of hours worked by high-skilled natives. In a slightly different perspective, Furtado and Hock (2010) evaluate how immigration affects the employmentmaternity trade-off in the USA.

Our paper adds to these results from several viewpoints. First, we perform a multi level, cross-country analysis. This allows us to obtain more general results and, using the cross-country dimension of our data set, to consider how unskilled migrants' labour supply interacts with the main features of the policies adopted to support the families. This is of particular importance as differences in social policies across OECD countries determine significant variations in women's labour market participation (see for example Del Boca et al. (2009), and Del Boca and Sauer (2009)). Second, these family policies are usually more effective for unskilled women, encouraging part-time work and jobs in lower level positions (Blau and Kahn, 2013). Then, in our empirical analysis we consider the effect on the labour supply of both skilled and unskilled female natives, while previous studies focused only on high skilled women. Third, we consider the role of unskilled migrants employed in a 
subgroup of service sectors compared to total labour force size. Finally, the theoretical model we adopt to analyse the labour supply decisions extends and generalizes the one of Cortés and Tessada (2011), and it avoids some of the less plausible implications of their model.

Our key assumption is that an increase in the concentration of unskilled migrants in services puts downward pressure on the local prices of household services such as housekeeping or childcare. As already mentioned, this assumption is empirically supported by the literature. In our theoretical model, household services bought on the market and own time are substitutes in household production. Hence, a decrease in the price of these services increases the native labour supply, under appropriate restrictions on their utility function. The full description and analysis of the model is in Section 2.

The remaining sections present our empirical analysis, which is based on the Cross-National Equivalent File (CNEF, Frick et al. (2012)), obtained with harmonized data from different national surveys. Specifically, we use the compatible surveys for three years (2001, 2003, and 2005) and for five countries (Australia, Germany, Switzerland, United Kingdom, and USA).

Our empirical strategy is to exploit the variability within region-year in the concentration of low-skilled immigrants in the service sector to identify their impact on the labour supply for native women. To address the potential endogeneity issues caused by the location choices of immigrants (since their distribution across regions is not random), and by measurement errors (due to undocumented migrants), we exploits the tendency of migrants to locate in regions with large share of migrants of the same origin, and use the past distribution of migrants across regions (Card, 2001).

We present three sets of results. First, we estimate the impact of migration on the labour market participation for native women with age 22 to 45 by skill level. Differently from what has been obtained in previous research, we find that there is a positive and statistically significant effect on the average probability to work of unskilled women. Consistently with the literature, there is no detectable impact on the labour market participation of skilled women.

Second, we test the empirical relationship between unskilled migration and hours worked per week. We observe that migration affects the number of hours worked at the top decile of the skilled women working hours distribution. Also, the incidence of migrants has positive effect on the probability of working more than 50 hours per week. On the other hand, there is no effect on the choices at the intensive margin of unskilled women. All these findings are particularly strong for women in households with kids. The results are robust to different sample compositions and identification tests. If we construct a mirror sample using native men as control group, we do not find any statistical relationship between incidence of migrants and native labour supply. This is consistent with our basic idea that unskilled migrants in services affect the native female labour supply because of their effect on the price of household services. Finally, we show that the impact of unskilled 
migration is stronger in countries where policies are less supportive to families.

The structure of the paper is the following. In the next section we present and discuss our theoretical model. In Section 3 we briefly present and discuss the (CNEF) data set. Section 4 introduces the empirical model, the identification strategy and the econometric specification. The empirical results are presented in Section 5. Section 6 discusses the interaction between effects on the labour supply and public policies. Some final considerations are in Section 7.

\section{The model}

In this section, we present and analyse a model of individual choice with household production. Inputs in this process are household's own labour and labour, good and services bought on the market at given prices and wages. We assume that they include labour supplied by low skilled immigrants and that the corresponding wage rate is decreasing in the concentration of unskilled immigrants active in the service sector in a given geographical area. ${ }^{1}$

We start discussing the behaviour of agents active on the labour market with a wage $w$, which coincides with the opportunity cost of time used in household production. Evidently, the wage depends upon various characteristics of the worker, including her human capital.

Each individual has preferences described by a utility function

$$
V(Y, \ell, R)=U(Y)+\psi \Psi(\ell)+\phi \Phi(R)
$$

where $Y$ denotes consumption (its price is normalized to 1 ), $\ell$ leisure time, $R$ household production, the output of the household production function described below. ${ }^{2}(\psi, \phi)$ are exogenous parameters, affecting the marginal utilities of $\ell$ and $R$. $R$ is obtained with a production function using as inputs goods and rented services (denoted $X$, with unit price $p$ ) and own time $(H)$ :

$$
R=F(X, H)
$$

satisfying standard assumptions (spelled out in Appendix A) and exhibiting constant returns to scale. Think of $X$ as a composite commodity, a bundle of goods and services which can be used as inputs by the household production technology. Personal services (such as baby sitting, household caring, plumbing and the like) are included in $X$. We assume that its unit price, $p$, is strictly decreasing in the prices of all the included goods and, in particular, in the wage of the household's employees, which is, in turn, decreasing in low skilled immigrants'

\footnotetext{
${ }^{1}$ Testing this assumption, we have found a negative correlation between the wage and the number of unskilled immigrants, in the household service sector. See Table 9, Section 5.1.

${ }^{2}$ With some abuse of language, we use $R$ to denote both the output of household production and a generic quantity of it. No ambiguity should arise.
} 
concentration, as explained above.

Each individual has a time endowment equal to 1 and a non-negative unearned income $I$ and faces three constraints: the technological constraint (1), the budget constraint,

$$
Y+w \ell+c(w, p) R \leq I+w
$$

where $w$ is the wage rate which, as usual, depends upon education, ability and the like ${ }^{3}$, and the feasibility constraints

$$
\begin{array}{r}
\ell+H+n=1 \\
(Y, \ell, H, X) \geq 0 \\
n \geq 0,
\end{array}
$$

where $n=(1-\ell-H)$ is the (market) labour supply.

As explained in Appendix A.1, the function $c(w, p)$ in $(2)$ is the (minimum) cost of producing one unit of $\operatorname{good} R$, given the technology and the prices of inputs. Let $h($.$) and x($.$) denote the conditional demand functions$ for inputs per unit of good $R$. Since returns to scale are constant, the actual demand for own time, for instance, is $h(w, p) R(w, p, I)$.

Individual behavior is described by the optimal solution to the problem

$$
\max _{(Y, \ell, R, X, H)} U(Y)+\psi \Psi(\ell)+\phi \Phi(R)
$$

subject to (1), (2) and (3).

Under standard assumptions on preferences (see Appendix A), (3b) is always satisfied at an optimal choice and, therefore, we will ignored it.

Let $\{Y(p, w, I), R(p, w, I), X(p, w, I), n(p, w, I), \ell(p, w, I), H(p, w, I)\}$ be the demand and supply functions. We are mainly interested in the properties of $n(p, w, I)$.

As we explain in Appendix A.2,

$$
\frac{\partial n}{\partial p}=-\frac{\partial \ell}{\partial p}-\left(\frac{\partial h}{\partial p} R(.)+\frac{\partial R}{\partial p} h(.)\right)=-\frac{\partial \ell}{\partial p}-\frac{R(.) h(.)}{p}\left(\frac{\partial h}{\partial p} \frac{p}{h(.)}+\frac{p}{R} \frac{\partial R}{\partial p}\right)
$$

Thus, the effect of a change in $p$ is given by (minus) the sum of two components: its effect on the demand for leisure, $\frac{\partial \ell}{\partial p}$, and its effect on the time devoted to household production. Since leisure is a normal good, income

\footnotetext{
${ }^{3}$ Notice that, given that the utility function is invariant across individuals, the difference between skilled and unskilled women is determined by their wage rates and outside incomes.
} 
and substitution effects have, as usual, opposite signs, so that the sign of $\frac{\partial \ell}{\partial p}$ is, in general, undefined. As shown in Appendix A.2, a necessary and sufficient condition for $\frac{\partial \ell}{\partial p}>0$ is that $\frac{\frac{\partial^{2} \Phi}{\partial R^{2}} R}{\frac{\partial \Phi}{\partial R}}>-1$, where $\left(\frac{\partial^{2} \Phi}{\partial R^{2}} R / \frac{\partial \Phi}{\partial R}\right)$ is a natural measure of the curvature of $\Phi($.$) (it is the Arrow-Pratt measure of relative risk aversion for the function$ $\Phi().){ }^{4}$

The second term in (4) depends upon the technological substitution between own labour and other inputs, given the demand for household production, which determines the value of $\frac{\partial h}{\partial p} R($.$) , and upon the effect of the$ change in $p$, hence in $c(p, w)$, on the demand for good $R$, which determines $\frac{\partial R}{\partial p} h($.$) . For instance, a decrease$ in $p$ decreases the demand for own labour per unit of household production via the technical substitution effect. However, it typically reduces the value of $c(w, p)$ and, therefore, it increases the demand for household production whenever this is a normal good. The net effect of a decrease in $p$ on the total input of own time is negative if the sum of the two elasticities (the term in round brackets in the last equation in (4)) is negative. This is guaranteed by a sufficiently high degree of technical substitutability. In our framework, this is a plausible assumption, since the "other inputs" include unskilled labour, which can be replaced one-to-one by own labour.

To sum up, a sufficient condition for an increase in low skilled immigrant concentration to have a positive effect on the native labour supply, via its effect on the equilibrium level of $p$, hence of $c($.$) , is given by$

1. $\frac{\partial^{2} \Phi}{\frac{\partial R}{2}} \frac{\partial \Phi}{\partial R} R>-1$,

2. $\left|\frac{\partial h}{\partial p} \frac{p}{h(\cdot)}\right|>\left|\frac{\partial R}{\partial p} \frac{p}{R(\cdot)}\right|$.

Assuming that preferences are invariant across individuals, the empirical distribution of $\frac{\partial n}{\partial p}$ depends upon the joint distribution of wages and unearned income. Even under our fairly restrictive assumptions, utility maximization does not impose any restriction on the signs of the second order derivatives, $\frac{\partial^{2} n}{\partial p \partial I}$ and $\frac{\partial^{2} n}{\partial p \partial w}$, that might very well be opposite, as in the parametric example presented below. Assume, for instance, that $\frac{\partial^{2} n}{\partial p \partial I}<0$, while $\frac{\partial^{2} n}{\partial p \partial w}>0$. If wage and unearned income are positively correlated, ${ }^{5}$ it is impossible to provide general results concerning the magnitude of $\frac{\partial n}{\partial p}$ at different levels of wages (and of unearned income), which is, therefore, a purely empirical issue and it is the core issue considered in our empirical analysis, where we estimate the impact of unskilled immigrant concentration on the native, female labour market choices at the intensive margin.

We summarize now some results concerning the effects of public policies on labour supply. They are formally established in Appendix A.2. First, unconditional income transfers have a negative effect on the labour supply, since $\frac{\partial n}{\partial I}<0$.

\footnotetext{
${ }^{4}$ This restriction is standard: in fact, it is a necessary and sufficient condition for the demand for leisure to be increasing in the price of each consumption good in the canonical model of labour supply with separable preferences.

${ }^{5}$ This is going to be the case, for instance, if there is assortative matching in household formation, since the partner's income enters into our definition of unearned income. This property is consistent with our empirical results.
} 
Secondly, policies related to household production can be described in the model either as affecting the marginal utility of $R$, e.g., as changing the value of the parameter $\phi$, or as free public supply of a fixed amount of public services. Consumption of household production is, then, the sum of two components: an amount $\underline{R}$ publicly provided and an additional amount obtained via household production, $R$. Other policies must best be seen as subsidies to the acquisition of the inputs $X$, which translate into reductions of their price $p$, so that the previous results apply.

In Appendix A.2, we show that

$$
\operatorname{sign} \frac{\partial n}{\partial \phi}=-\operatorname{sign} \frac{\partial n}{\partial \underline{R}}=\operatorname{sign}\left(\psi \frac{\partial^{2} \Psi}{\partial \ell^{2}} h(.)-\frac{\partial^{2} U}{\partial Y^{2}} w p x(.)\right)
$$

and they are not uniquely defined. However, it is easy to check that $\frac{w p x(.)}{h(.)}$ is strictly increasing in $w$. If, additionally, the second order derivatives of the utility function are constant (i.e., the function is quadratic or "almost" quadratic), changes in $(\phi, \underline{R})$ might have opposite effects at different levels of the wage distribution. In particular, it can be $\frac{\partial n}{\partial \psi}>0$ at low $w$ and $\frac{\partial n}{\partial \psi}<0$ at high wage levels, while the opposite is true for $\frac{\partial n}{\partial \underline{R}}$. An example might clarify some of the issues just discussed.

Example 1 Assume that preferences are described by a Cobb-Douglas utility function

$$
V(Y, R, \ell)=\ln Y+\psi \ln \ell+\phi \ln (\underline{R}+R),
$$

so that, at $\underline{R}=0$, the demand functions are, $Y()=.\frac{I+w}{1+\psi+\phi}, \ell()=.\frac{\psi(I+w)}{(1+\psi+\phi) w}, R()=.\frac{\phi(I+w)}{(1+\psi+) c(p, w)}$. Assume that $I$ is sufficiently small, so that $\ell()<$.1 . The household production function is a CES, $R=\left\{\chi_{x} X^{\mu}+\chi_{h} H^{\mu}\right\}^{\frac{1}{\mu}}$. Then,

$$
c(p, w)=\left\{\chi_{x}\left(\frac{p}{\chi_{x}}\right)^{\frac{\mu}{\mu-1}}+\chi_{h}\left(\frac{w}{\chi_{h}}\right)^{\frac{\mu}{\mu-1}}\right\}^{\frac{\mu-1}{\mu}}
$$

and

$$
H(.)=R\left\{\chi_{x}\left(\frac{p}{\chi_{x}}\right)^{\frac{\mu}{\mu-1}}+\chi_{h}\left(\frac{w}{\chi_{h}}\right)^{\frac{\mu}{\mu-1}}\right\}^{\frac{-1}{\mu}}\left(\frac{w}{\chi_{h}}\right)^{\frac{1}{\mu-1}}
$$

It follows that

$$
\frac{\partial n}{\partial p}=-\left(\frac{\partial h}{\partial p} R(.)+\frac{\partial R}{\partial p} h(.)\right)=\frac{\mu}{\mu-1} \frac{\phi(I+w)}{(1+\psi+\phi) c(.)^{2}}\left(\frac{p}{\chi_{x}}\right)^{\frac{1}{\mu-1}}\left(\frac{w}{\chi_{h}}\right)^{\frac{1}{\mu-1}} .
$$

Evidently, $\frac{\partial n}{\partial p}<0$, as long as $\mu>0$. Straightforward computations also show that $\frac{\partial^{2} n}{\partial p \partial I}<0$, while $\frac{\partial^{2} n}{\partial p \partial w}>0$.

Before considering the case where the non-negativity constraint is binding, let's compare our model to the one adopted by Cortés and Tessada (2011). The notation is the same. There are two essential differences. First, in their model $R$ is a constraint, while we treat it as a choice variable. Secondly, they consider a specific, quasi- 
linear, production function $\bar{R}=X+f(H)$. Jointly, these two assumptions drastically simplify the analysis. Given $(p, w)$, the optimal value of $H$ is directly determined and, since $\bar{R}$ is fixed, the quantity $X$ is also immediately determined by the household production constraint, $X(p, w, \bar{R})=\bar{R}-f(H(p, w))$. Hence, their model is isomorphic to one where the only choice is between leisure and consumption. Since their specification entails properties that are at variance with our empirical results, it is worthwhile to get into some detail in the comparison of the two models.

First, observe that, if $\bar{R}$ is fixed and the production function is quasi-linear, we can rewrite the budget constraint as

$$
C+w \ell=I+w-w H(.)-p(\bar{R}-f(H(.))) \equiv \widehat{I}(p, w, I) .
$$

Straightforward computations show that

$$
\frac{\partial n}{\partial p}=-\frac{\partial h}{\partial p} R(.)+\frac{\frac{\partial U^{2}}{\partial Y^{2}} w}{\frac{\partial U^{2}}{\partial Y^{2}} w+\frac{\partial \Psi^{2}}{\partial \ell^{2}}} x(.) R(.) .
$$

Since $\frac{\partial h}{\partial p}$ is positive, the sign of $\frac{\partial n}{\partial p}$ is, in general, undetermined. However, it is negative if $x()=$.0 , i.e., in this model, for sufficiently small wage levels.

The authors also claim that $\frac{\partial n}{\partial p}$ is (in absolute value) decreasing with respect to unearned income and to the wage rate. ${ }^{6}$

For sure, their specification of the model presents several advantages. However, for our purposes, they come at a substantial cost, since its basic structure has implications which are both somewhat counter-intuitive and, more relevant, at variance with our empirical results. In particular, our Table 6 shows that having young children has a negative effect on the (market) labour supply. In their model, the most natural assumption seems to be that having young children entails a larger value of the constraint $\bar{R}$, i.e., of the required, exogenously given, level of household production. However, a change in $\bar{R}$ does not have any effect on $H($.$) , since this just$ depends upon the ratio $\frac{w}{p}$, and, from (5) above, $\frac{\partial \widehat{I}(w, p)}{\partial \bar{R}}=-p$, so that

$$
\frac{\partial n}{\partial \bar{R}}=-\frac{\partial \ell}{\partial \widehat{I}} \frac{\partial \widehat{I}(w, p)}{\partial \bar{R}}=p \frac{\partial \ell}{\partial \widehat{I}}>0
$$

As already mentioned, this property is violated in our data. ${ }^{7}$ These are some of our motivations for looking at

\footnotetext{
${ }^{6}$ Both results are not formally established in the paper and are somewhat difficult to understand. They write "agents with higher unearned income (and therefore higher use of market provided household services, $X$ )...". However, with $\bar{R}$ fixed and a quasi-linear production function, both $H($.$) and X($.$) are determined just by the real wage, so that they are invariant with respect$ to unearned income. Moreover, it is easy to construct examples satisfying all the assumptions of the model and such that $\frac{\partial n}{\partial p}$ does not depend upon unearned income. For instance, assume that $R=X+2 \sqrt{H}$, and $V()=.\ln C+\ln \ell$. It is easy to check that $\frac{\partial n}{\partial p}=\frac{\bar{R}}{2 w}+\frac{p}{w^{2}}$, which is $I$-invariant.

${ }^{7}$ In their set-up, a decrease in the market labour supply can be obtained if the existence of young children increases the marginal utility of leisure, without affecting $\bar{R}$.
} 
the more general model described here, which is not inconsistent with our empirical findings.

Consider now the case of the agents for whom the constraint $n \geq 0$ is binding. Let $\theta$ be the Kuhn-Tucker multiplier of the non-negativity constraint.

Given $(\phi, \psi, p)$, let $(w, I(w))$ the set of pairs such that $n(p, w ; I(w))=\theta(p, w ; I(w))=0$, i.e., such that the optimal solution to the (unconstrained) optimization problem is zero. We have already shown above that $\frac{\partial n(p, w ; I)}{\partial I}<0$. Under some additional restrictions on preferences, spelled out in Appendix A, $\frac{\partial n}{\partial w}>0$. Thus, the locus of pairs $(w, I(w))$ such that $n(p, w ; I(w))=\theta(p, w ; I(w))=0$ might be monotonically increasing in $(w, I)$-space. Evidently, marginal changes in $p$ affect the participation behaviour just for the agents such that their pair $(w, I(w))$ lies on the locus just described. Hence, empirically, the effect on labour market participation depends on:

1. the properties of the empirical distribution $(w, I)$ compared to the locus $(w, I(w))$,

2. the sign of the left and right derivatives $\left(\frac{\partial n}{\partial p^{-}}, \frac{\partial n}{\partial p^{+}}\right)$.

Our empirical results propose some sort of puzzle, since, for individuals, native female, with low education (and low wage) changes in $p$ do not have any significant effect on the hours of labour, i.e., on the choices at the intensive margin (see Table 5). However, for the same group of people, they have a significant effect at the extensive margin: specifically, decreases in $p$ increase labour market participation (see Table 6). Bear in mind that, in our dataset, participation on the labour market requires a minimum, strictly positive number of hours of work, $\underline{n}$. Therefore, the notion of derivative is perfectly well defined if we consider the potential labour supply, i.e., the supply function computed ignoring the constraint $n \geq \underline{n}$. Call this unconstrained labour supply $n^{*}(p, w, I)$.

There are four sets of agents: the ones such that $n^{*}(p, w, I)>\underline{n}$, the ones such that $n^{*}(p, w, I)<\underline{n}$ and it is optimal to accept a job, the ones such that $n^{*}(p, w, I)<\underline{n}$ and it is optimal not to accept a job. Finally, the ones with $n^{*}(p, w, I)<\underline{n}$ and indifferent between accepting and rejecting a job. At the margin, changes in $p$ affect the labour market participation only for this last group of agents. Let's consider just this subgroup. Assume that all of them actually choose not to work and that, for agent $i$, the derivative for this potential labour supply is $\frac{\partial n_{i}}{\partial p}=f(p, w, I)+\varepsilon_{i}$, where $\varepsilon_{i}$ is a zero mean idiosyncratic term. If $f(p, w, I)=0$ the price change has no systematic effect on the labour supply at the intensive margin. However, for all the agents such that $\varepsilon_{i}>0$, the decrease in $p$ makes strictly optimal to take a job. For all the agents such that $\varepsilon_{i}<0$, it makes strictly optimal not to take a job, so that there is no change in their behaviour. Therefore, in the aggregate we have positive effect on labour market participation. 


\section{$3 \quad$ Data and descriptive statistics}

In this section, we introduce the basic details of the data on migration, and labour market supply we use to test the main predictions of the model. The Cross-National Equivalent File (CNEF) is the main source that provides cross country equivalent information for individuals and households. We also consider the Annual Community Survey (ACF) for USA, Labour Force Survey (LFS) for UK, and Sustainable Governance Indicators. ${ }^{8}$ At first, we describe CNEF project, and then the additional sources as well as indicators for family policies. Details are reported in Appendix B.

\section{Cross-National Equivalent File}

We use Cross-National Equivalent File as the main source for both natives and migrants labour supply. CNEF is an international project that encompasses individual and household data from national surveys with equivalently defined variables. ${ }^{9}$ The unit of analysis in the CNEF is the household, and information are collected periodically for all individuals of a representative panel of households. The main advantage is that CNEF allows international cross-country comparison in the socio-economic behaviour of individuals and households. This is of particular interest in our study as we aim at analysing how country's social policies and migrants' intensity interact with female labour supply. The CNEF, in fact, includes countries which notably differ in terms of family policies (see Section 6).

The equivalent data can be used independently or jointly with the original national survey data. However, the equivalence cannot be fully retrieved by merging single national surveys; within national surveys special algorithm are implemented to generate equivalent variables. The surveys cover a wide range of topics, such as employment status, income, household type, educational attainment, birthplace, region of residence, etc. To exploit the panel dimension of our dataset, we have to restrict the set of waves to year 2001, 2003, and 2005 for Australia (AUS), Germany (GER), United Kingdom (UK), Switzerland (CH), and USA.

The smaller panel dimension can be seen as a shortcoming of our dataset, so that we are able to provide only a short term analysis. ${ }^{10}$ However, compared to the previous studies in the literature, this allows us to conduct a cross-country analysis on the impact of unskilled immigrants on native female labour supply, accounting for the heterogeneity of countries family policies. ${ }^{11}$

Another shortcoming of the CNEF is that, for UK and USA, it is not possible to calculate regional labour supply of migrants, because no data are collected for foreign born individuals. However, this missing piece of

\footnotetext{
${ }^{8} \mathrm{~A}$ resume for data-sources is reported in Table C.1

${ }^{9}$ The CNEF was primarily developed to increase the accessibility, the use, and the comparability of panel data among crossnational surveys.

${ }^{10}$ Model's comparative statics is consistent with both short term and long term analysis.

${ }^{11}$ Note that all the other studies focus on single country analysis. For instance, Barone and Mocetti (2011) for Italy, Cortés and Tessada (2011) for USA, and Farré et al. (2011) for Spain. All these countries adopt low supportive family policies.
} 
information can be easily obtained from the Labour Force Surveys for UK, and the Annual Community Survey for USA. Nonetheless, what is crucial for our analysis is the cross country equivalence of information on the estimation units (native women), and the CNEF is specifically designed for that.

\section{Native women}

A native is an individual that self-declare to be national born. ${ }^{12}$ The estimation sample includes women with age 22 to 45, who are married, cohabitant with partners, or single as head of the household, and who are not enrolled in school. ${ }^{13}$ In this way, we can focus on women with young children, or in fecund age, for which the link between time spent in household production and labour market participation is stronger. ${ }^{14}$ In Section 5.1, we test the robustness of our results by including in the estimation sample women with age 46 to 65 .

Independently on the data source, we define skilled a woman who has achieved a bachelor degree or a higher degree. In order to eliminate unrealistic observations, we drop individuals above the $99^{t h}$ percentile of the household income, wage, and working hours distributions (by country). The final estimation sample contains 27573 native women.

Table 1 displays some descriptive statistics of the estimation sample by country and skill levels. Generally, women account for more than half of the native population. ${ }^{15}$ Households' characteristics vary across countries. For example, $90 \%$ of women in Australia and UK declare to be married (or legally cohabitant with a partner), while in Germany only $69 \%$ are married. Differences among countries exist for the average number of kids (overall and by age brackets), in particular Germany has the lowest share of women with at least a child of age 0-1 (7\% compared with an average of $13 \%$ in the full sample).

Not surprisingly, educational level strongly affects the labour supply of native women. On average, skilled women have higher participation rates, supply more hours per week, and earn higher wages. $85 \%$ of skilled women are employed, and supply on average 34 hours per week, while only $76 \%$ of unskilled are employed, and supply 31 hours per week on average. ${ }^{16}$

However, given the different institutional settings and national characteristics, the comparison of averages among countries cannot be very informative. Table 2 shows that in each country the distribution of working hours per week might vary substantially: for example in Switzerland the median value of hours per week is 30 , whereas in the US is 37 .

\footnotetext{
${ }^{12}$ In Switzerland, a native is a person with Swiss first nationality.

${ }^{13}$ We do not include women who live with parents, or women in the army.

${ }^{14}$ Also Del Boca et al. (2009), which studies the impact of social policies on women's decisions regarding work and childbearing, exclude women still enrolled in school or university (age 16-21) and who have a low probability of being fecund (age 45-65).

${ }^{15} \mathrm{UK}$ has the larger female population share $(63 \%)$, while in Switzerland it is 9 percentage point below the UK one. Moreover, the share of skilled female in the labour force is $61 \%$ in UK and $39 \%$ in Switzerland.

${ }^{16} \mathrm{It}$ is interesting to note that within countries labour supply of skilled and unskilled women differ significantly both at the extensive, and intensive margins. In Appendix $\mathrm{C}$ we test whether the differences between the averages of the two groups is statistically significant. Skilled women are more likely to participate to the labour market, and supply more hours, on average. The gaps within countries are statistically significant (see Table C.2, columns Dif. I and Dif. II).
} 
Table 1: Native women's descriptive statistics ${ }^{\ddagger}$

\begin{tabular}{|c|c|c|c|c|c|c|}
\hline & \multicolumn{5}{|c|}{ All } & \multirow[b]{2}{*}{ Total } \\
\hline & AUS & $\mathrm{CH}$ & GER & UK & USA & \\
\hline Pop. share & 0.56 & 0.54 & 0.57 & 0.63 & 0.55 & 0.56 \\
\hline Participation & 0.73 & 0.76 & 0.77 & 0.82 & 0.84 & 0.79 \\
\hline Hour per Week & 32.46 & 29.09 & 32.13 & 30.86 & 33.26 & 31.98 \\
\hline Age & 34.69 & 36.23 & 35.61 & 35.06 & 34.78 & 35.26 \\
\hline Married & 0.90 & 0.79 & 0.69 & 0.92 & 0.71 & 0.78 \\
\hline Child 0-1 & 0.16 & 0.10 & 0.07 & 0.18 & 0.17 & 0.13 \\
\hline Child 2-4 & 0.23 & 0.19 & 0.16 & 0.14 & 0.25 & 0.19 \\
\hline Child 5-7 & 0.23 & 0.23 & 0.18 & 0.22 & 0.25 & 0.22 \\
\hline Child 8-10 & 0.24 & 0.24 & 0.17 & 0.21 & 0.25 & 0.21 \\
\hline Num. Children & 0.41 & 0.31 & 0.24 & 0.34 & 0.44 & 0.34 \\
\hline Hourly Wage PPP & 20.18 & 15.75 & 13.81 & 12.62 & 15.71 & 15.29 \\
\hline HH Gross Income & 10.30 & 10.32 & 9.76 & 10.07 & 10.02 & 10.02 \\
\hline \multirow[t]{3}{*}{ Old People in HH } & 0.09 & 0.08 & 0.01 & 0.00 & 0.07 & 0.04 \\
\hline & \multicolumn{5}{|c|}{ Skilled } & \\
\hline & AUS & $\mathrm{CH}$ & GER & UK & USA & Total \\
\hline Pop. share & 0.60 & 0.39 & 0.53 & 0.61 & 0.57 & 0.53 \\
\hline Participation & 0.85 & 0.85 & 0.84 & 0.87 & 0.86 & 0.85 \\
\hline Hour per Week & 34.66 & 32.72 & 34.21 & 34.15 & 33.49 & 34.21 \\
\hline Age & 34.40 & 36.17 & 36.32 & 33.97 & 35.25 & 35.29 \\
\hline Married & 0.87 & 0.76 & 0.66 & 0.86 & 0.75 & 0.76 \\
\hline Child 0-1 & 0.17 & 0.12 & 0.08 & 0.09 & 0.17 & 0.14 \\
\hline Child 2-4 & 0.22 & 0.22 & 0.18 & 0.17 & 0.26 & 0.22 \\
\hline Child 5-7 & 0.20 & 0.22 & 0.18 & 0.16 & 0.26 & 0.22 \\
\hline Child 8-10 & 0.19 & 0.15 & 0.14 & 0.14 & 0.26 & 0.20 \\
\hline Num. Children & 0.41 & 0.37 & 0.27 & 0.29 & 0.44 & 0.37 \\
\hline Hourly Wage PPP & 23.38 & 19.14 & 17.35 & 16.96 & 18.31 & 19.06 \\
\hline HH Gross Income & 10.26 & 10.36 & 9.72 & 10.14 & 10.23 & 10.12 \\
\hline \multirow[t]{3}{*}{ Old People in $\mathrm{HH}$} & 0.08 & 0.09 & 0.01 & 0.00 & 0.06 & 0.05 \\
\hline & \multicolumn{5}{|c|}{ Unskilled } & \\
\hline & AUS & $\mathrm{CH}$ & GER & UK & USA & Total \\
\hline Pop. share & 0.53 & 0.62 & 0.58 & 0.64 & 0.53 & 0.56 \\
\hline Participation & 0.66 & 0.73 & 0.76 & 0.81 & 0.82 & 0.76 \\
\hline Hour per Week & 30.54 & 27.84 & 31.47 & 29.92 & 32.96 & 31.14 \\
\hline Age & 34.87 & 36.26 & 35.48 & 35.33 & 34.44 & 35.30 \\
\hline Married & 0.92 & 0.80 & 0.70 & 0.93 & 0.66 & 0.78 \\
\hline Child 0-1 & 0.15 & 0.09 & 0.06 & 0.20 & 0.16 & 0.12 \\
\hline Child 2-4 & 0.24 & 0.18 & 0.16 & 0.13 & 0.24 & 0.18 \\
\hline Child 5-7 & 0.26 & 0.23 & 0.18 & 0.23 & 0.25 & 0.22 \\
\hline Child 8-10 & 0.27 & 0.26 & 0.17 & 0.22 & 0.26 & 0.22 \\
\hline Num. Children & 0.40 & 0.30 & 0.23 & 0.36 & 0.41 & 0.32 \\
\hline Hourly Wage PPP & 17.52 & 14.47 & 12.66 & 11.46 & 12.54 & 13.27 \\
\hline HH Gross Income & 10.32 & 10.30 & 9.77 & 10.06 & 9.75 & 9.97 \\
\hline Old People in HH & 0.10 & 0.08 & 0.01 & 0.00 & 0.07 & 0.04 \\
\hline \multicolumn{7}{|c|}{$\begin{array}{l}\text { Sample includes women with age } 22 \text { to } 45 \text { who are not enrolled in school, who are married, cohabitant } \\
\text { with partners, or single as head of the household. Individual sample weights have been applied. Pop } \\
\text { share: share of native women on total native population. Participation: share of employed women. Child } \\
\text { share of women with at least a child in a given range of age. Num. Child: number of children in women's } \\
\text { household. Hourly Wage PPP: gross earnings per hour in PPP US dollar for private consumption in } \\
\text { 2000. HH Gross Income: women's household gross income at exchange rate in PPP US dollar for private } \\
\text { consumption in } 2000 \text { in thousand of euros. Old People in HH: people older than } 65 \text { in women's household }\end{array}$} \\
\hline
\end{tabular}


Table 2: Weekly working hour distribution by country, by skill level. ${ }^{\ddagger}$

\begin{tabular}{l|cccc}
\hline & $25^{\text {th }}$ pct & $50^{\text {th }}$ pct & $75^{\text {th }}$ pct & $90^{\text {th }}$ pct \\
\hline Panel $A$ & \multicolumn{4}{|c}{ All } \\
AUS & 22.00 & 36.00 & 40.00 & 46.00 \\
CH & 18.00 & 30.00 & 42.00 & 45.00 \\
GER & 20.98 & 36.98 & 40.96 & 44.96 \\
UK & 21.06 & 35.10 & 39.11 & 45.12 \\
USA & 26.54 & 36.92 & 40.00 & 46.54 \\
\hline Panel B & \multicolumn{4}{|c}{ Skilled } \\
AUS & 25.00 & 38.00 & 44.00 & 50.00 \\
CH & 24.00 & 35.00 & 42.00 & 45.00 \\
GER & 24.98 & 38.96 & 42.31 & 46.63 \\
UK & 27.25 & 37.10 & 42.11 & 47.13 \\
USA & 27.12 & 36.62 & 40.38 & 47.31 \\
\hline Panel C & \multicolumn{4}{|c}{ Unskilled } \\
AUS & 20.00 & 32.73 & 40.00 & 45.00 \\
CH & 16.00 & 30.00 & 42.00 & 45.00 \\
GER & 19.98 & 35.98 & 40.48 & 44.96 \\
UK & 20.05 & 35.09 & 38.10 & 44.12 \\
USA & 25.58 & 36.92 & 40.00 & 45.00 \\
\hline \hline
\end{tabular}

$\ddagger$ Source: our calculation from CNEF data. The distributions are calculated on the weekly hour supply of employed native women by country (Panel A) and country/skill level.

\section{Migrants}

We define a migrant as a foreign born individual. CNEF surveys of Australia and Germany report information on birthplace. For Switzerland, a migrant is a person with foreign first nationality. Unfortunately, UK and USA surveys include few or none foreign born individuals. Then, we need to collect information on migrants from alternative data sources. The best database to identify migrants as foreign borns (at the regional level) for UK and USA are LFS and ACS, respectively. Foreign status and country of birth are used to calculate migrants' labour supply and instrumental variable at region-year pairs (using sampling weights).

A migrant in the age brackets of 16-64 is considered part of the services' labour force, if he/she declares to be employed in one of the following sectors ${ }^{17}$ : health and social work, other services to person, household services, hotel and restaurant. As natives, migrants are unskilled if they declare to have obtained a high school degree or lower educational attainment. ${ }^{18}$ Labour supply of migrants is matched at regional-year level with individual labour supply of natives women. Regional classification in each country has been made coherent among the different data sources.

Table 3 displays the share of unskilled migrants working in household service sector on migrants' total (and unskilled) labour market supply. On average unskilled migrants in service sector are not a negligible component, and account for $11 \%$ and $20 \%$ of migrants' total and unskilled labour force, respectively i.e., every five lowskilled migrants, one declares to be employed in the household service sector. Moreover, unskilled migrants in

\footnotetext{
${ }^{17}$ See country notes in Section B for more details on the service sectors we have included in the analysis. Notice that Barone and Mocetti (2011) consider as migrants in household production the female migrants from Ecuador, Moldavia, Morocco, Peru, Philippines, Poland, Romania, Russia, Sri Lanka, and Ukraine. A similar approach is followed by Furtado and Hock (2010). Differently, we do not discriminate migrants according to origin or gender, but with respect to educational level.

${ }^{18}$ Given that our identification strategy relies on the past geographical distribution of migrants by country of origin, we retain in our sample only migrants from countries for which information on the distribution of migrants by region in the early nineties are available.
} 
services account for $11 \%$ of total unskilled labour force, and $15 \%$ of native unskilled labour force in the household services. ${ }^{19}$ More details on the data are available upon request.

\begin{tabular}{|c|c|c|c|c|c|c|c|c|}
\hline & \multicolumn{4}{|c|}{$\frac{\text { UnskMigrServ }}{\text { Migrants }}$} & \multicolumn{4}{|c|}{$\frac{\text { UnskMigrServ }}{\text { Unskilled Migrants }}$} \\
\hline & 2001 & 2003 & 2005 & Total & 2001 & 2003 & 2005 & Total \\
\hline Australia & 0.070 & 0.091 & 0.091 & 0.084 & 0.100 & 0.130 & 0.129 & 0.120 \\
\hline Switzerland & 0.154 & 0.117 & 0.085 & 0.118 & 0.211 & 0.164 & 0.132 & 0.170 \\
\hline Germany & 0.067 & 0.060 & 0.062 & 0.063 & 0.112 & 0.112 & 0.103 & 0.109 \\
\hline United Kingdom & 0.127 & 0.154 & 0.046 & 0.109 & 0.168 & 0.204 & 0.227 & 0.200 \\
\hline USA & 0.116 & 0.135 & 0.133 & 0.128 & 0.229 & 0.248 & 0.242 & 0.240 \\
\hline Total & 0.115 & 0.121 & 0.098 & 0.111 & 0.191 & 0.199 & 0.192 & 0.194 \\
\hline
\end{tabular}

\section{Empirical model}

In this section we describe the empirical approach we adopt to test the predictions of the model. As explained in Section 2, inputs used in the household production $(R)$ are household's own time $(H)$ and labour, goods and services $(X)$ bought on the market, which include labour supplied by low skilled immigrants. The corresponding wage rate is assumed to be decreasing in the concentration of unskilled immigrants active in the services sector, in a given area (region). Previous empirical evidence suggests that an increase in the share of low-skilled migrants puts downward pressure on the prices of immigrants intensive sectors (Cortés (2008) for USA), or sectors with high concentration of low-wage workers (Frattini (2012) for UK). Similarly, our data show the existence of a negative correlation between migrants' labour supply in household service sector and the gross wages of unskilled working in the same sector (see Table 9). The model presented in Section 2 predicts that a decrease in prices of household services positively affects the labour supply of native women at the intensive margin (i.e. $\partial n / \partial p<0$ ), whereas the effect on participation to the labour market, i.e., at the extensive margin, is ambiguous.

\subsection{Identification strategy}

To identify the impact of a variation in prices of the household service sector on the labour supply of native women, we exploit the variability (within region-year) of the concentration of low-skilled immigrants employed in this specific sector. ${ }^{20}$

\footnotetext{
${ }^{19}$ See Appendix C, Table C.3. In addition, there exists a large variability of labour supply of migrants within countries: for example in UK, migrants' labour supply in the Inner London is four time larger than the concentration in Rest of North West region (Table C.4).

${ }^{20}$ We implicitly assume that migrants and natives supply labour in the area they reside.
} 
We measure the concentration of migrants as the ratio of unskilled migrants employed in household service sector $^{21}$, UnskMigrServ ${ }_{r t}$, to total labour force of natives, DomLF $F_{r t}$, and migrants, MigrLF $F_{r t} .^{22}$ For each country, immigration intensity in region $r$, at time $t$ is defined as follows,

$$
\text { Migr. Services }{ }_{r t}=\frac{\text { UnskMigrServ }_{r t}}{\text { DomLF }_{r t}+\text { MigrLF }_{r t}} \in[0,1]
$$

The identification strategy that relies on the regional distribution of migrants presents two concerns. First, migrants are not evenly distributed across regions. If the location choice is not random, the regional concentration of migrants could be endogenous to native women's labour supply. The endogeneity bias might arise from omitted variables and reverse causality. Unobservable factors (e.g., regional level of economic development) might affect simultaneously the attractiveness of a region (for migrants), and the natives' labour supply. Moreover, reverse causality bias the estimates if low-skilled migrants are attracted in regions where the demand for their job (household services) is high, namely in regions where natives women work more intensively. Thus, reverse causality and unobservable factors generate an overestimation of the causal effect of migration, and ordinary least square tend to be upward biased. A second source of concern is the presence of undocumented migrants in the household service sector. The indicator of migrants' regional concentration, Eq. 6, does not consider (by construction) labour supplied by not-regular workers. Similarly, unemployed migrants who provide household services in the black market are not accounted for. In this case, Migr. Services $r$ can underestimate the role of migrants, so that the measurement error generates downward biased estimates of OLS. ${ }^{23}$

The last problem is realted to the mobility of natives as a response to migrants' labour supply shocks. It is reasonable to think that natives respond to international migration by moving across regions to re-equilibrate unbalances across local labour markets. However, here we do not account for this displacement effect for two reasons. First, the sample period is very short. Second, there is no strong empirical evidence of a significant displacement effect of natives due to migration. Borjas (2006) shows the existence of displacement for US natives but not perfectly offsetting. Instead, Card and Lewis (2007) and, more recently, Peri and Sparber (2011), using different datasets and techniques provide evidence against the existence of natives' displacement in USA. Moreover, for European regions (Zimmermann, 2009) shows that labour mobility is not relevant. ${ }^{24}$ From a macroeconomic perspective, Docquier et al. (2013) find that incoming migrants do not have a negative effect on the employment rate of natives in the OECD countries.

\footnotetext{
${ }^{21}$ For a more detailed description of household service sector, see Section 3 .

${ }^{22}$ Note that the numerator includes only migrants that self-declare employed in household service sector, while the denominator accounts for all individuals (migrants and natives) in the working age (from 16 to 65).

${ }^{23}$ Endogeneity bias might also arise from unobservable factors such as preferences to social norms: people with same preferences and attitudes can locate in the same area.

${ }^{24}$ Similarly, migration seems to have a small impact on natives' wage. See, for instance, Peri and Sparber (2009) for USA; Brücker and Jahn (2011), and D'Amuri et al. (2010) for Germany; Manacorda et al. (2012) for United Kingdom. It should be noticed that all these studies consider the overall effect of immigration on native wage rates. In this paper, we focus on a specific sector, where migrants are relatively more concentrated.
} 


\subsection{Instrumental variable}

Regional and year fixed effects partially address endogeneity concerns. To deal with the mentioned issues, we adopt a standard instrumental variable strategy that relies on the past distribution of migrants by country of origin (Card, 2001). ${ }^{25}$ This instrument captures the tendency of migrants to locate in regions with a large share of migrants with the same origin. Network effects influence migrants' location choice reducing the integration costs faced by newcomers, and facilitating the job search process. For each country in the sample, we consider the 1990 distribution of migrants by country of origin and region of destination. ${ }^{26}$ For each country $c$, we predict the number of low-skilled immigrants (in services) in region $r$ and year $t$ (numerator of Eq. 6) with

$$
\text { Unsk } \widehat{M i g r} S e r v_{r t}=\sum_{j} \frac{\text { Immigr }_{j r c 1990}}{\text { Immigr }_{j c 1990}} * \text { UnskMigrServ } v_{j c t}
$$

where $\sum_{j} \frac{\text { Immigr }_{j r c 1990}}{\text { Immigr }_{j c 1990}}$ is the share of immigrants from origin $j$, living in region $r$, within country $c$, in the census year (1990). ${ }^{27}$ The second term, UnskMigrServ ${ }_{j c t}$, stands for the total number of unskilled migrants (in household services) from origin $j$, living in country $c$, in year $t$. The predicted stock of unskilled migrants, Unsk $\widehat{M i g r} S e r v_{r t}$, is scaled by the regional population ${ }^{28}$ in $1990^{29}$, i.e.,

$$
\text { Instr }_{r c t}=\frac{U n s k \widehat{M i g r} \operatorname{Serv}_{r t}}{\text { RegPop }_{r c 1990}}
$$

Our instrument identifies the causal effects of unskilled migration on the native women's labour supply as long as it satisfies two conditions. First, the instrument must have strong predictive power for the endogenous variable. Second, it should not have a direct impact on contemporaneous labour market shocks (exclusion restriction): the unobserved factors that determine migrants' location choice in census year must be uncorrelated with contemporaneous variations of the regional economic conditions (and labour supply of natives). ${ }^{30}$

As a preliminary test on the instrument's validity, we perform a first stage analysis using observations at regional level. ${ }^{31}$ We regress our indicator of migration intensity in services (Eq 6) on instrument (Eq 8), and a set of control variable. Table 4 displays the estimated coefficients. The instrument is highly correlated with our measure of migrants' labour supply in household services. The associated F-statistics is above 10, so that

\footnotetext{
${ }^{25}$ A similar approach has been applied by Barone and Mocetti (2011); Cortés and Tessada (2011); Farré et al. (2011); Furtado and Hock (2010).

${ }^{26}$ For the description census data see country notes in Appendix B.

${ }^{27}$ As usual, we consider migrants of all ages from 0 to 99 .

${ }^{28}$ We prefer to use regional population in 1990 , because it is less likely to be correlated with contemporaneous labour market shocks.

${ }^{29}$ Data Source: OECD Statistics Database

${ }^{30} \mathrm{An}$ additional concern for the violation of the exclusion restriction is that changes in prices or availability of household services are not the only channels through which low-skilled immigration affects the labour supply of native women. To partial out the effects of these variables, we present specifications that excludes unskilled women employed in service sectors, as well as a specification that includes only native men.

${ }^{31}$ Table C.5 in Appendix C reports descriptive statistics of the main explanatory variables and the instrument.
} 
we can reject the hypothesis of weak instrumentation (Stock and Yogo, 2002). The inclusion of additional control variables addresses the concern about the exclusion restriction: the magnitude and the significance of the coefficients do not vary (see columns 2,3 , and 4$).{ }^{32}$

\begin{tabular}{|c|c|c|c|c|}
\hline & (1) & $\overline{(2)}$ & (3) & (4) \\
\hline Instr $_{r c t}$ & $\begin{array}{c}1.314^{* * *} \\
{[0.101]}\end{array}$ & $\begin{array}{c}1.240^{* * *} \\
{[0.104]}\end{array}$ & $\begin{array}{c}1.115^{* * *} \\
{[0.110]}\end{array}$ & $\begin{array}{c}1.135^{* * *} \\
{[0.111]}\end{array}$ \\
\hline Constant & $\begin{array}{c}0.003^{* * *} \\
{[0.001]}\end{array}$ & $\begin{array}{l}0.004^{*} \\
{[0.002]}\end{array}$ & $\begin{array}{c}-0.091^{* * *} \\
{[0.034]}\end{array}$ & $\begin{array}{c}-0.125^{* *} \\
{[0.054]}\end{array}$ \\
\hline Obs. & 348 & 348 & 347 & 347 \\
\hline $\mathrm{R}^{2}$ & 0.336 & 0.353 & 0.399 & 0.407 \\
\hline Control & no & no & Ind. & Ind. \& Regi. \\
\hline Fixed Effects & no & country/year & country/year & country/year \\
\hline F-Stat & 169.4 & 34.28 & 24.44 & 21.88 \\
\hline \multicolumn{5}{|c|}{$\begin{array}{l}\ddagger \text { OLS estimation. Significance level: } * 0.10>\mathrm{p} \text {-value } * * 0.05>\mathrm{p} \text {-value }{ }^{* * *} 0.01>\mathrm{p} \text {-value. } \\
\text { Robust standard errors are reported in squared brackets. Dependent variable is mi- } \\
\text { grants in services, Eq. } 6 \text {. The number of Obs. is the number of regions by the number } \\
\text { of countries by the number of years. Control variables are divided in two groups: in- } \\
\text { dividual and regional. Individual controls (Ind.) are weighted averages (by region, by } \\
\text { year) of population age, marital status, gross households' income, number of children } \\
\text { per household. Regional controls (Regi.) are female participation rate, unemployment } \\
\text { rate, GDP per worker, and population density (by region, by year). }\end{array}$} \\
\hline
\end{tabular}

\subsection{Econometric specification}

To investigate the effects of unskilled migrants on female natives' labour supply at the intensive margin in region $r$, country $c$, at time $t$, we estimate the following equation for employed women $i$,

$$
L S_{i r c t}=\alpha_{0}+\alpha_{1}(\text { Migr. Service })_{r c t}+\sum_{n} \beta_{n} \mathbf{X}_{i t}+\sum_{n} \gamma_{n} \mathbf{H H}_{h t}+\sum_{n} \delta_{n} \mathbf{R}_{r t}+R D_{r}+T D_{t}+u_{i t}
$$

where $L S_{i r c t}$ is a measure of labour supply's intensity for employed native women. Similarly to Cortés and Tessada (2011), we use a binary indicator to measure the intensive margin of labour supply. The indicator relies on the distribution of women's working hours across countries (see Table 2). The distribution support is defined by country and skill level. The dependent variable takes value one if a native woman supplies an amount of weekly hours above a given percentile of the underlying distribution, otherwise it is zero. ${ }^{33} 34$ According to our theoretical framework, we expect a positive and significant sign for $\alpha_{1}$. In Section 5 we will present the estimated results.

We now introduce the equation that we use to estimate the impact of migrants' labour supply on female

\footnotetext{
${ }^{32}$ The individual controls (Ind.) are weighted averages (by region, by year) of population age, marital status, gross households' income, number of children per household. The same control variables will be used, at individual level, in the main empirical analysis. Regional controls (Regi.) include female participation rate, unemployment rate, GDP per worker, and population density (by region, by year). Finally, we include region and year fixed effects.

${ }^{33}$ For example, if an employed native woman supplies an amount of hours above the 90th percentile of hours' distribution (by country and educational level), the dependent variable takes value one, otherwise zero.

${ }^{34}$ Alternatively, we define a dummy variable that takes value one if a native woman works more than $x$ hours per week, otherwise it is zero. Given systematic differences across countries, we prefer the former indicator, because it provides an homogeneous measure of the intensive margin between countries.
} 
natives' participation rate. In this case, we consider as dependent variable the employment status of a native women. Given the individual $i$, in region $r$, country $c$, at time $t$, we estimate

$$
\text { Partirct }_{i}=\alpha_{0}+\alpha_{1}(\text { Migr. Service })_{r c t}+\sum_{n} \beta_{n} \mathbf{X}_{i t}+\sum_{n} \gamma_{n} \mathbf{H H}_{h t}+\sum_{n} \delta_{n} \mathbf{R}_{r t}+R D_{r}+T D_{t}+u_{i t}
$$

where Part $_{\text {irct }}$ is equal to one if a native woman has a paid job, zero otherwise. In Section 2, we explained that it is not possible to provide general results on the magnitude and sign of this effect. This is, therefore, a purely empirical issue.

Eq. 9 and Eq. 10 are estimated with a linear probability model. Vectors $\mathbf{X}, \mathbf{H H}$, and $\mathbf{R}$ define the controls at the individual, household, and regional levels, respectively. In the first group, we include age, age squared, skill level, marital status, and dummies which capture the presence of children in different age brackets in the family. In the second group, we consider the log of gross household income ${ }^{35}$ (in US dollar PPP 2000), and its squared term, as well as the number of elderly people in the household (older than 65). Regional controls are female labour market participation, and unemployment rates. ${ }^{36}$ We include also regional $(R D)$ and year $(T D)$ fixed effects to control for systematic differences between regions and business cycle. ${ }^{37}$ Given that Migr. Service varies between region-year pairs and individual labour supply is not independent within regions, standard errors are clustered at regional-year level.

\section{Estimation results}

Intensive margin - Table 5 reports the estimates of Eq. 9. The table is divided in four panels. Each panel represents a set of estimations with their own dependent variables. Within each panel, the columns report the results for different specifications. The sample includes only employed native women. All of them include individual, household, and regional controls, which are not reported for the sake of space. In the first two columns of each panel, we show that regional concentration of unskilled migrants in services is positively, but not significantly, correlated with the labour supply of native women (both OLS and IV). Then, we consider separately low and high skilled native women. The coefficient of Migr. Service ${ }_{r c t}$ is statistically significant only in panel D (column 4). It suggests that in regions where the concentration of unskilled immigrants in household services is higher, it is more likely that skilled women above the $90^{\text {th }}$ percentile of the hours' distribution, decide to work longer hours.

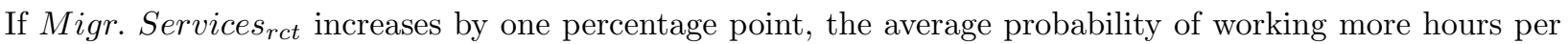
week increases by 6.05 percentage points. As a basis of comparison, consider that having at least one child aged

\footnotetext{
${ }^{35}$ Household income is the sum of all gross earnings of household members minus woman gross earnings

${ }^{36}$ Data Source: OECD Statistics Database

${ }^{37}$ Table C.6 in Appendix C reports a detailed description of control variables.
} 
2 to 4 reduces by 6.6 percentage points the probability of increasing the labour supply of skilled native women. Instead, we do not find any significant effect for unskilled female natives (columns 5 and 6). In the last two columns (7 and 8) of each panel, we refine the sample by excluding unskilled individuals which are employed in the household service sector. We aim at eliminating women that directly compete with immigrants in the service sector. The inclusion of this group potentially bias the estimation as long as native and immigrants are perfect substitute in production function, so that an increase of immigrants will lower native wages. Nonetheless, in our estimations, we continue to observe a positive but not significant effect.

The findings in Table 5 are coherent with the results presented in Section 2 , since the magnitude of $\partial n / \partial p$ varies at different level of earned wages. Given that wages are positively correlated with education levels, it is not surprising to find that unskilled and skilled natives react differently to a migrant labour supply shock. Moreover, our results are in line with the previous empirical evidence (Barone and Mocetti, 2011; Cortés and Tessada, 2011; Farré et al., 2011). Besides, the sign and significance of estimated coefficients of additional control variables are in line with the literature. ${ }^{38}$

\footnotetext{
${ }^{38}$ Estimations available upon request.
} 
Table 5: Intensive margin of labour supply - percentile of weekly labour supply ${ }^{\ddagger}$.

\begin{tabular}{|c|c|c|c|c|c|c|c|c|}
\hline & $\begin{array}{c}(1) \\
\text { OLS } \\
\text { All } \\
\end{array}$ & $\begin{array}{l}(2) \\
\text { IV } \\
\text { All }\end{array}$ & $\begin{array}{c}(3) \\
\text { OLS } \\
\text { Skilled }\end{array}$ & $\begin{array}{c}(4) \\
\text { IV } \\
\text { Skilled } \\
\end{array}$ & $\begin{array}{c}(5) \\
\text { OLS } \\
\text { Unsk. }\end{array}$ & $\begin{array}{c}(6) \\
\text { IV } \\
\text { Unsk. }\end{array}$ & $\begin{array}{c}(7) \\
\text { OLS } \\
\text { Unsk NS }\end{array}$ & $\begin{array}{c}(8) \\
\text { IV } \\
\text { Unsk. NS }\end{array}$ \\
\hline Panel $A$ & & & \multicolumn{4}{|c|}{$\operatorname{Pr}\left(\right.$ Hours $\geq 25^{t h}$ pct $)$} & & \\
\hline Migr. service $_{r t}$ & $\begin{array}{c}1.015 \\
{[0.753]}\end{array}$ & $\begin{array}{c}8.240 \\
{[6.257]}\end{array}$ & $\begin{array}{c}4.625^{* *} \\
{[1.805]}\end{array}$ & $\begin{array}{c}7.912 \\
{[6.021]}\end{array}$ & $\begin{array}{l}-0.419 \\
{[0.997]}\end{array}$ & $\begin{array}{c}7.890 \\
{[7.291]}\end{array}$ & $\begin{array}{c}9.796 \\
{[7.180]}\end{array}$ & $\begin{array}{l}11.282 \\
{[9.162]}\end{array}$ \\
\hline Obs. & 18,334 & 18,334 & 6,177 & 6,177 & 12,157 & 12,157 & 14,960 & 8,783 \\
\hline $\mathrm{R}^{2}$ & 0.185 & 0.182 & 0.202 & 0.202 & 0.188 & 0.184 & 0.184 & 0.189 \\
\hline F-Stat & . & 15.74 & . & 22.02 & . & 13.14 & 17.12 & 14.24 \\
\hline Control & yes & yes & yes & yes & yes & yes & yes & yes \\
\hline Region \& year FE & yes & yes & yes & yes & yes & yes & yes & yes \\
\hline Panel B & & & \multicolumn{4}{|c|}{$\operatorname{Pr}\left(\right.$ Hours $\geq 50^{t h}$ pct $)$} & & \\
\hline Migr. service $_{r t}$ & $\begin{array}{c}0.566 \\
{[1.289]}\end{array}$ & $\begin{array}{c}4.464 \\
{[3.932]}\end{array}$ & $\begin{array}{c}1.711 \\
{[2.671]}\end{array}$ & $\begin{array}{c}8.776 \\
{[7.762]}\end{array}$ & $\begin{array}{c}-0.142 \\
{[1.332]}\end{array}$ & $\begin{array}{c}2.227 \\
{[4.928]}\end{array}$ & $\begin{array}{c}4.420 \\
{[4.420]}\end{array}$ & $\begin{array}{c}1.946 \\
{[5.103]}\end{array}$ \\
\hline Obs. & 18,334 & 18,334 & 6,177 & 6,177 & 12,157 & 12,157 & 14,960 & 8,783 \\
\hline $\mathrm{R}^{2}$ & 0.198 & 0.198 & 0.198 & 0.196 & 0.215 & 0.215 & 0.201 & 0.229 \\
\hline F-Stat & 年 & 15.74 & . & 22.02 & . & 13.14 & 17.12 & 14.24 \\
\hline Control & yes & yes & yes & yes & yes & yes & yes & yes \\
\hline Region \& year FE & yes & yes & yes & yes & yes & yes & yes & yes \\
\hline Panel $C$ & & & \multicolumn{4}{|c|}{$\operatorname{Pr}\left(\right.$ Hours $\geq 75^{t h}$ pct $)$} & & \\
\hline Migr. service $r t$ & $\begin{array}{l}-0.042 \\
{[1.177]}\end{array}$ & $\begin{array}{c}3.084 \\
{[2.998]}\end{array}$ & $\begin{array}{c}0.960 \\
{[2.266]}\end{array}$ & $\begin{array}{l}-2.984 \\
{[3.745]}\end{array}$ & $\begin{array}{l}-0.288 \\
{[1.340]}\end{array}$ & $\begin{array}{c}6.058 \\
{[4.560]}\end{array}$ & $\begin{array}{c}6.051 \\
{[3.765]}\end{array}$ & $\begin{array}{c}12.012^{*} \\
{[6.245]}\end{array}$ \\
\hline Obs. & 18,334 & 18,334 & 6,177 & 6,177 & 12,157 & 12,157 & 14,960 & 8,783 \\
\hline $\mathrm{R}^{2}$ & 0.115 & 0.114 & 0.095 & 0.094 & 0.136 & 0.134 & 0.113 & 0.135 \\
\hline F-Stat & onter & 15.74 & . & 22.02 & . & 13.14 & 17.12 & 14.24 \\
\hline Control & yes & yes & yes & yes & yes & yes & yes & yes \\
\hline Region \& year FE & yes & yes & yes & yes & yes & yes & yes & yes \\
\hline Panel D & & & \multicolumn{4}{|c|}{$\operatorname{Pr}\left(\right.$ Hours $\geq 90^{t h}$ pct $)$} & & \\
\hline Migr. service $_{r t}$ & $\begin{array}{l}-0.399 \\
{[0.890]}\end{array}$ & $\begin{array}{c}3.588 \\
{[2.463]}\end{array}$ & $\begin{array}{c}1.634 \\
{[1.622]}\end{array}$ & $\begin{array}{c}6.053^{* * *} \\
{[2.134]}\end{array}$ & $\begin{array}{l}-0.971 \\
{[0.923]}\end{array}$ & $\begin{array}{c}2.486 \\
{[3.879]}\end{array}$ & $\begin{array}{l}4.171^{*} \\
{[2.477]}\end{array}$ & $\begin{array}{c}2.730 \\
{[4.372]}\end{array}$ \\
\hline Obs. & 18,334 & 18,334 & 6,177 & 6,177 & 12,157 & 12,157 & 14,960 & 8,783 \\
\hline $\mathrm{R}^{2}$ & 0.049 & 0.048 & 0.065 & 0.063 & 0.053 & 0.052 & 0.054 & 0.063 \\
\hline F-Stat & & 15.74 & . & 22.02 & . & 13.14 & 17.12 & 14.24 \\
\hline Control & yes & yes & yes & yes & yes & yes & yes & yes \\
\hline Region \& year FE & yes & yes & yes & yes & yes & yes & yes & yes \\
\hline \multicolumn{9}{|c|}{$\begin{array}{l}\ddagger \text { Linear probability model. Each column represents a different regression for employed native women. Table } \\
\text { reports only the coefficient of Migr. service (Eq. } 6 \text {. Significance level: } * 0.10>\text { p-value, } * * 0.05>\text { p-value, } \\
* * * 0.01>\text { p-value. Errors are clustered at the region X year level, and are reported in squared brackets. } \\
\text { F-Stat is the Kleibergen-Paap rk statistic. All estimations include the following controls: age, age squared, } \\
\text { marital status, dummy for children with age } 0-12-45-7 \text {, household gross earnings minus women earnings } \\
\text { and its squared term, number of elderly people in the household. Columns } 1 \text { and } 2 \text { include an indicator } \\
\text { for individual educational level. Regional controls include unemployment rate, and female participation } \\
\text { rate. All: sample of all natives women. Skilled: sample of natives skilled women. Unsk: sample of natives } \\
\text { unskilled women. Unsk NS: sample of natives unskilled women not employed in household service sectors. } \\
\text { Female hourly work distribution is constructed by country and skill level. }\end{array}$} \\
\hline
\end{tabular}

As a robustness check, we estimate Eq. 9 considering as dependent variable the probability to work more than a fixed amount of hours per week. ${ }^{39}$ The results confirm that in regions with higher concentration of unskilled immigrants in services, the probability of working more than 50 hours per week is higher and statistically significant only for skilled natives. ${ }^{40}$

Extensive margin - The estimation results from Eq. 10 are presented in Table 6. Each column represents a different specification of the equation. In the first three columns, we focus on the whole sample of native women. Probit and OLS estimates show a positive correlation between natives' participation rate and labour

\footnotetext{
${ }^{39}$ In this case the dependent variable does not vary by country but rather by skill level.

${ }^{40}$ Results are reported in Appendix C, Table C.7.
} 
supply of unskilled migrants (columns 1 and 2). The IV model estimates that an increase of 1 percentage point in Migr. Services leads to an increase of 7 percentage points of the probability of native women to be employed $\left(\right.$ column 3). ${ }^{41}$

Similarly to previous analysis, we split the estimation sample by skill level. Our main findings are that regional concentration of unskilled migrants in services does not affect labour supply of skilled women at the extensive margin (columns 4 and 5). Interestingly, it positively affects the participation rate of unskilled natives (columns 6 and 7). If Migr. Services increases by 1 percentage point, the labour supply of low-skilled natives raises by 10 percentage points at the extensive margin (ceteris paribus). ${ }^{42}$ The comparison of coefficients in columns 3,5 , and 7 shows that only the participation rate of unskilled native women is affected by migrants' labour supply in services.

As before, we retain in the estimation sample unskilled native women who are not employed in the household service sector (columns 8 and 9). The estimated coefficient shows that migrants' labour supply has a stronger effect on the participation rate of unskilled natives women, as we have eliminated the downward bias due to a possible perfect substitutability effect in production. ${ }^{43}$

Finally, the control variables report sign and significance in line with the literature. Unskilled women who are married or with children are less likely to be employed (columns 7 and 9) compared to the skilled one (column 5). In general, skilled and more experienced (age) women have higher participation rate.

In conclusion, the estimation results in Table 6 establish two important results. First, the regional concentration of unskilled migrants in services has a positive impact on the labour supply of unskilled native women at the extensive margin. Second, our findings are robust to competition effect in the labour market of household services. We do not find any significant effects for skilled native women.

\footnotetext{
${ }^{41}$ The F-Stat supports, again, the strength of our instrument.

${ }^{42}$ Alternatively, an increase of $10 \%$ in the main explanatory variable generates an increase of 1.46 percentage points in participation rate of unskilled natives.

${ }^{43}$ The IV coefficient of Migr. Services in column 9 is larger compared to the correspondent one in column 7.
} 
Table 6: Extensive margin of labour supply. ${ }^{\ddagger}$

\begin{tabular}{|c|c|c|c|c|c|c|c|c|c|}
\hline & $\begin{array}{c}(1) \\
\text { Probit } \\
\text { All }\end{array}$ & $\begin{array}{c}(2) \\
\text { OLS } \\
\text { All }\end{array}$ & $\begin{array}{l}(3) \\
\text { IV } \\
\text { All }\end{array}$ & $\begin{array}{c}(4) \\
\text { OLS } \\
\text { Skilled }\end{array}$ & $\begin{array}{c}(5) \\
\text { IV } \\
\text { Skilled }\end{array}$ & $\begin{array}{c}(6) \\
\text { OLS } \\
\text { Unsk. }\end{array}$ & $\begin{array}{c}(7) \\
\text { IV } \\
\text { Unsk. }\end{array}$ & $\begin{array}{c}(8) \\
\text { OLS } \\
\text { Unsk NS }\end{array}$ & $\begin{array}{c}(9) \\
\text { IV } \\
\text { Unsk. NS }\end{array}$ \\
\hline Migr. service $r t$ & $\begin{array}{c}1.510^{* *} \\
{[0.611]}\end{array}$ & $\begin{array}{c}1.481^{* * *} \\
{[0.565]}\end{array}$ & $\begin{array}{c}7.061^{* * *} \\
{[1.892]}\end{array}$ & $\begin{array}{c}0.440 \\
{[1.376]}\end{array}$ & $\begin{array}{l}-0.398 \\
{[2.531]}\end{array}$ & $\begin{array}{c}1.938^{* * *} \\
{[0.636]}\end{array}$ & $\begin{array}{c}10.449^{* * *} \\
{[2.728]}\end{array}$ & $\begin{array}{c}1.810^{* *} \\
{[0.761]}\end{array}$ & $\begin{array}{c}14.148^{* * *} \\
{[3.892]}\end{array}$ \\
\hline Skilled $_{i r t}$ & $\begin{array}{c}0.081^{* * *} \\
{[0.010]}\end{array}$ & $\begin{array}{c}0.078^{* * *} \\
{[0.011]}\end{array}$ & $\begin{array}{c}0.078^{* * *} \\
{[0.011]}\end{array}$ & & & & & & \\
\hline Age $_{i r t}$ & $\begin{array}{c}0.036^{* * *} \\
{[0.009]}\end{array}$ & $\begin{array}{c}0.035^{* * *} \\
{[0.008]}\end{array}$ & $\begin{array}{c}0.035^{* * *} \\
{[0.008]}\end{array}$ & $\begin{array}{c}0.040^{* *} \\
{[0.016]}\end{array}$ & $\begin{array}{c}0.040^{* * *} \\
{[0.015]}\end{array}$ & $\begin{array}{c}0.035^{* * *} \\
{[0.009]}\end{array}$ & $\begin{array}{c}0.036^{* * *} \\
{[0.009]}\end{array}$ & $\begin{array}{c}0.044^{* * *} \\
{[0.011]}\end{array}$ & $\begin{array}{c}0.046^{* * *} \\
{[0.011]}\end{array}$ \\
\hline $\operatorname{Age}^{2}{ }_{i r t}$ & $\begin{array}{c}-0.001 * * * \\
{[0.000]}\end{array}$ & $\begin{array}{c}-0.001 * * * \\
{[0.000]}\end{array}$ & $\begin{array}{c}-0.001 * * * \\
{[0.000]}\end{array}$ & $\begin{array}{c}-0.001 * * * \\
{[0.000]}\end{array}$ & $\begin{array}{c}-0.001 * * * \\
{[0.000]}\end{array}$ & $\begin{array}{c}-0.001^{* * *} \\
{[0.000]}\end{array}$ & $\begin{array}{c}-0.001 * * * \\
{[0.000]}\end{array}$ & $\begin{array}{c}-0.001 * * * \\
{[0.000]}\end{array}$ & $\begin{array}{c}-0.001 * * * \\
{[0.000]}\end{array}$ \\
\hline Child(01) irt & $\begin{array}{c}-0.110^{* * *} \\
{[0.025]}\end{array}$ & $\begin{array}{c}-0.111^{* * *} \\
{[0.025]}\end{array}$ & $\begin{array}{c}-0.109^{* * *} * \\
{[0.025]}\end{array}$ & $\begin{array}{c}-0.100^{* * *} \\
{[0.033]}\end{array}$ & $\begin{array}{c}-0.100 * * * \\
{[0.033]}\end{array}$ & $\begin{array}{c}-0.120^{* * *} \\
{[0.029]}\end{array}$ & $\begin{array}{c}-0.118^{* * *} \\
{[0.029]}\end{array}$ & $\begin{array}{c}-0.084^{* * *} \\
{[0.032]}\end{array}$ & $\begin{array}{c}-0.081^{* *} \\
{[0.032]}\end{array}$ \\
\hline Child $(24)_{i r t}$ & $\begin{array}{c}-0.290^{* * *} \\
{[0.019]}\end{array}$ & $\begin{array}{c}-0.304^{* * *} \\
{[0.020]}\end{array}$ & $\begin{array}{c}-0.304^{* * *} \\
{[0.020]}\end{array}$ & $\begin{array}{c}-0.232^{* * *} \\
{[0.030]}\end{array}$ & $\begin{array}{c}-0.232^{* * *} \\
{[0.030]}\end{array}$ & $\begin{array}{c}-0.331^{* * *} \\
{[0.022]}\end{array}$ & $\begin{array}{c}-0.331^{* * *} \\
{[0.022]}\end{array}$ & $\begin{array}{c}-0.366^{* * *} \\
{[0.027]}\end{array}$ & $\begin{array}{c}-0.366^{* * * *} \\
{[0.027]}\end{array}$ \\
\hline Child(57) $i r t$ & $\begin{array}{c}-0.125^{* * *} \\
{[0.018]}\end{array}$ & $\begin{array}{c}-0.137^{* * *} \\
{[0.020]}\end{array}$ & $\begin{array}{c}-0.137^{* * *} \\
{[0.020]}\end{array}$ & $\begin{array}{c}-0.111^{* * *} * \\
{[0.034]}\end{array}$ & $\begin{array}{c}-0.111^{* * *} \\
{[0.034]}\end{array}$ & $\begin{array}{c}-0.145^{* * *} \\
{[0.027]}\end{array}$ & $\begin{array}{c}-0.145^{* * *} \\
{[0.026]}\end{array}$ & $\begin{array}{c}-0.174^{* * *} \\
{[0.031]}\end{array}$ & $\begin{array}{c}-0.176^{* * *} \\
{[0.030]}\end{array}$ \\
\hline Marit. Status $_{i r t}$ & $\begin{array}{c}-0.077^{* * *} * \\
{[0.014]}\end{array}$ & $\begin{array}{c}-0.068^{* * *} \\
{[0.013]}\end{array}$ & $\begin{array}{c}-0.068^{* * *} \\
{[0.013]}\end{array}$ & $\begin{array}{c}-0.058^{* *} \\
{[0.024]}\end{array}$ & $\begin{array}{c}-0.058^{* *} \\
{[0.024]}\end{array}$ & $\begin{array}{c}-0.071^{* * * *} \\
{[0.016]}\end{array}$ & $\begin{array}{c}-0.071^{* * *} \\
{[0.016]}\end{array}$ & $\begin{array}{c}-0.094^{* * *} \\
{[0.020]}\end{array}$ & $\begin{array}{c}-0.094^{* * *} \\
{[0.020]}\end{array}$ \\
\hline HH Income $_{i r t}$ & $\begin{array}{l}-0.000 \\
{[0.012]}\end{array}$ & $\begin{array}{c}0.007 \\
{[0.006]}\end{array}$ & $\begin{array}{c}0.008 \\
{[0.006]}\end{array}$ & $\begin{array}{c}0.026^{* * *} * \\
{[0.008]}\end{array}$ & $\begin{array}{c}0.026^{* * *} \\
{[0.008]}\end{array}$ & $\begin{array}{l}-0.001 \\
{[0.007]}\end{array}$ & $\begin{array}{c}0.000 \\
{[0.007]}\end{array}$ & $\begin{array}{c}0.001 \\
{[0.009]}\end{array}$ & $\begin{array}{c}0.002 \\
{[0.009]}\end{array}$ \\
\hline HH Income ${ }^{2}$ irt & $\begin{array}{l}-0.001 \\
{[0.008]}\end{array}$ & $\begin{array}{c}-0.001^{* *} \\
{[0.000]}\end{array}$ & $\begin{array}{c}-0.001^{* *} \\
{[0.000]}\end{array}$ & $\begin{array}{c}-0.002^{* * *} \\
{[0.001]}\end{array}$ & $\begin{array}{c}-0.002^{* * *} \\
{[0.001]}\end{array}$ & $\begin{array}{l}-0.001 \\
{[0.001]}\end{array}$ & $\begin{array}{l}-0.001 \\
{[0.001]}\end{array}$ & $\begin{array}{l}-0.001 \\
{[0.001]}\end{array}$ & $\begin{array}{l}-0.001 \\
{[0.001]}\end{array}$ \\
\hline Num.Old $_{i r t}$ & $\begin{array}{c}0.033^{* *} \\
{[0.013]}\end{array}$ & $\begin{array}{c}0.038^{* *} \\
{[0.015]}\end{array}$ & $\begin{array}{c}0.037^{* *} \\
{[0.015]}\end{array}$ & $\begin{array}{c}0.044^{* * *} \\
{[0.016]}\end{array}$ & $\begin{array}{c}0.044^{* * *} \\
{[0.016]}\end{array}$ & $\begin{array}{l}0.036^{*} \\
{[0.020]}\end{array}$ & $\begin{array}{c}0.033 \\
{[0.020]}\end{array}$ & $\begin{array}{l}0.048^{*} \\
{[0.027]}\end{array}$ & $\begin{array}{c}0.042 \\
{[0.027]}\end{array}$ \\
\hline Constant & . & $\begin{array}{c}1.104^{* * *} \\
{[0.191]}\end{array}$ & $\begin{array}{c}1.139^{* * *} \\
{[0.216]}\end{array}$ & $\begin{array}{c}1.131^{* * *} \\
{[0.302]}\end{array}$ & $\begin{array}{c}1.140 * * * \\
{[0.300]}\end{array}$ & $\begin{array}{c}1.014^{* * *} * \\
{[0.240]}\end{array}$ & $\begin{array}{c}1.103^{* * *} \\
{[0.283]}\end{array}$ & $\begin{array}{c}1.134^{* * *} \\
{[0.250]}\end{array}$ & $\begin{array}{c}1.106^{* * *} \\
{[0.355]}\end{array}$ \\
\hline Obs. & 22,630 & 22,655 & 22,655 & 7,030 & 7,030 & 15,625 & 15,625 & 12,153 & 12,153 \\
\hline Control & yes & yes & yes & yes & yes & yes & yes & yes & yes \\
\hline $\begin{array}{l}\text { Region \& year FE } \\
\mathrm{R}^{2}\end{array}$ & yes & $\begin{array}{c}\text { yes } \\
0.181\end{array}$ & $\begin{array}{c}\text { yes } \\
0.176\end{array}$ & $\begin{array}{c}\text { yes } \\
0.163\end{array}$ & $\begin{array}{c}\text { yes } \\
0.163\end{array}$ & $\begin{array}{c}\text { yes } \\
0.186\end{array}$ & $\begin{array}{c}\text { yes } \\
0.181\end{array}$ & $\begin{array}{c}\text { yes } \\
0.215\end{array}$ & $\begin{array}{c}\text { yes } \\
0.206\end{array}$ \\
\hline F-Stat & . & . & 15.78 & . & 23.55 & . & 13.01 & . & 13.55 \\
\hline
\end{tabular}

\subsection{Robustness analysis}

So far, we have found that the regional concentration of unskilled immigrants affects positively both the probability of low-skilled native women to be employed, and the probability of high-skilled women to work longer hours.

In this section, we verify the robustness of these findings. First, we estimate the empirical model on a larger sample that includes elder women. Second, we test whether migrants employed in the household service sector affect the participation rates and the working hours of native male. Third, we control if the transmission channel from migrants' labour supply to prices is confirmed by our data.

Elder women - We analyse the women's trade-off between labour market supply and household production by including in the estimation sample individuals aged from 22 to 45 (Del Boca et al., 2009). ${ }^{44}$ Potentially, the labour supply of young women might be more constrained by household duties related to childcare. To test if the results are driven by this effect, we re-estimate Eq. 9 and Eq. 10 including in the sample women aged from

\footnotetext{
${ }^{44}$ By excluding women 21 years old and younger, we minimize the concern about the trade-off between education and labour market participation.
} 
21 to 65 (unrestricted sample). To sum up, we replicate, using the unrestricted sample, the estimates reported in columns 4 and 5 (panel D), Table 5 , as well as the ones in columns 6, 7, 8, and 9, Table 6.

Table 7 displays the estimation results. We observe that the participation rate of unskilled natives is still affected by the labour supply of unskilled migrants in the household service sector (columns 1 and 2). The

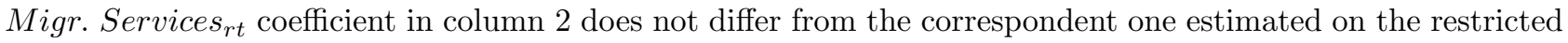
sample (column 7, Table 6). The result also holds when we control for native women employed in household service sector (columns 3 and 4).

However, when we exclude unskilled women in services (column 4), we obtain a smaller coefficient than the one estimated for the restricted sample (column 9, Table 6). This suggests that the positive impact of migrants' labour supply is more relevant for young unskilled women rather than for older women.In columns 5 and 6 , we analyse how skilled women's labour supply at the intensive margin (fixing the threshold at the $90^{\text {th }}$ percentile) changes with variations in the regional concentration of unskilled migrants. The IV estimate shows that the probability to work longer hours of skilled women increases as migrants' concentration raises (fixing the threshold at the $90^{t h}$ percentile). Compared to the restricted sample (panel $\mathrm{D}$, Table 5), the estimated coefficient is smaller (4.46, vs 6.05).

Given that the sign and significance of coefficients do not change between the two samples, we can conclude that childcare responsibilities are not the only barrier to women's labour supply. However, younger women face a stronger trade-off between labour supply and household activities: the estimations suggest that the marginal effect of an increase in Migr. Services $r$ is higher for the labour supply of young women compared to older women, at both the intensive (column 6) and the extensive (column 4) margins.

Besides, it is also interesting to observe that the coefficient of Num.Old changes between restricted and unrestricted sample. In particular, Table 6 shows that the number of old people living in the household (i.e., older than 65) has a positive but not significant effect on the labour market participation of unskilled women, while the same variable shows a negative sign in the unrestricted sample. In the former case (restricted sample), old people in the household might be retired relatives who provide support for childcare or housekeeping activities. In the latter case (unrestricted sample), old people are more likely to be senior individuals that needs medical treatments and supplemental care. Given that unskilled earn lower wages than skilled, it is more likely that the care of old household members bears upon them (from columns 1 to 4). 
Table 7: Robustness checks, sample age 22-64

\begin{tabular}{|c|c|c|c|c|c|c|}
\hline & \multicolumn{2}{|c|}{$\begin{array}{l}\text { Part. } \\
\text { Unsk. }\end{array}$} & \multicolumn{2}{|c|}{$\begin{array}{c}\text { Part. } \\
\text { Unsk NS }\end{array}$} & \multicolumn{2}{|c|}{$\begin{array}{c}\operatorname{Pr}\left(\text { Hours } \geq 90^{t h} \text { pct }\right) \\
\text { Skilled }\end{array}$} \\
\hline & $\begin{array}{c}\text { OLS } \\
(1)\end{array}$ & $\begin{array}{l}\text { IV } \\
(2)\end{array}$ & $\begin{array}{c}\text { OLS } \\
(3) \\
\end{array}$ & $\begin{array}{l}\text { IV } \\
(4)\end{array}$ & $\begin{array}{c}\text { OLS } \\
(5)\end{array}$ & $\begin{array}{l}\text { IV } \\
(6)\end{array}$ \\
\hline Migr. service $_{r t}$ & $\begin{array}{c}2.796^{* * *} * \\
{[0.639]}\end{array}$ & $\begin{array}{c}10.084^{* * *} \\
{[1.723]}\end{array}$ & $\begin{array}{c}2.479^{* * *} \\
{[0.797]}\end{array}$ & $\begin{array}{c}10.596^{* * *} \\
{[1.999]}\end{array}$ & $\begin{array}{c}0.846 \\
{[0.772]}\end{array}$ & $\begin{array}{c}4.461^{* * *} \\
{[1.542]}\end{array}$ \\
\hline $\operatorname{Age}_{i r t}$ & $\begin{array}{c}0.056^{* * *} \\
{[0.003]}\end{array}$ & $\begin{array}{c}0.056^{* * *} \\
{[0.003]}\end{array}$ & $\begin{array}{c}0.052^{* * *} \\
{[0.003]}\end{array}$ & $\begin{array}{c}0.052^{* * *} \\
{[0.003]}\end{array}$ & $\begin{array}{c}0.003 \\
{[0.004]}\end{array}$ & $\begin{array}{c}0.003 \\
{[0.004]}\end{array}$ \\
\hline Agee $_{i r t}^{2}$ & $\begin{array}{c}-0.001 * * * \\
{[0.000]}\end{array}$ & $\begin{array}{c}-0.001 * * * \\
{[0.000]}\end{array}$ & $\begin{array}{c}-0.001 * * * \\
{[0.000]}\end{array}$ & $\begin{array}{c}-0.001 * * * \\
{[0.000]}\end{array}$ & $\begin{array}{c}-0.000^{* *} \\
{[0.000]}\end{array}$ & $\begin{array}{c}-0.000^{* *} \\
{[0.000]}\end{array}$ \\
\hline Child (0-1) $i r t$ & $\begin{array}{c}-0.113^{* * *} \\
{[0.027]}\end{array}$ & $\begin{array}{c}-0.110^{* * *} \\
{[0.027]}\end{array}$ & $\begin{array}{c}-0.079^{* *} \\
{[0.031]}\end{array}$ & $\begin{array}{c}-0.076^{* *} \\
{[0.031]}\end{array}$ & $\begin{array}{c}-0.061^{* * *} \\
{[0.012]}\end{array}$ & $\begin{array}{c}-0.059 * * * \\
{[0.012]}\end{array}$ \\
\hline Child $(2-4)_{i r t}$ & $\begin{array}{c}-0.329 * * * \\
{[0.022]}\end{array}$ & $\begin{array}{c}-0.329 * * * \\
{[0.022]}\end{array}$ & $\begin{array}{c}-0.364^{* * * *} \\
{[0.026]}\end{array}$ & $\begin{array}{c}-0.364^{* * * *} \\
{[0.026]}\end{array}$ & $\begin{array}{c}-0.056^{* * *} \\
{[0.009]}\end{array}$ & $\begin{array}{c}-0.055^{* * *} \\
{[0.009]}\end{array}$ \\
\hline Child (5-7) $i r t$ & $\begin{array}{c}-0.161^{* * *} \\
{[0.025]}\end{array}$ & $\begin{array}{c}-0.161^{* * *} \\
{[0.025]}\end{array}$ & $\begin{array}{c}-0.186^{* * *} \\
{[0.030]}\end{array}$ & $\begin{array}{c}-0.186^{* * * *} \\
{[0.030]}\end{array}$ & $\begin{array}{c}-0.047^{* * * *} \\
{[0.011]}\end{array}$ & $\begin{array}{c}-0.047^{* * *} \\
{[0.011]}\end{array}$ \\
\hline Marit.Status $_{i r t}$ & $\begin{array}{c}-0.106^{* * *} * \\
{[0.013]}\end{array}$ & $\begin{array}{c}-0.105^{* * *} \\
{[0.013]}\end{array}$ & $\begin{array}{c}-0.116^{* * *} \\
{[0.015]}\end{array}$ & $\begin{array}{c}-0.116^{* * *} \\
{[0.015]}\end{array}$ & $\begin{array}{c}-0.032^{* * *} * \\
{[0.012]}\end{array}$ & $\begin{array}{c}-0.031^{* * *} \\
{[0.012]}\end{array}$ \\
\hline HH Income $i r t$ & $\begin{array}{c}0.017^{* * *} \\
{[0.006]}\end{array}$ & $\begin{array}{c}0.017^{* * *} \\
{[0.006]}\end{array}$ & $\begin{array}{c}0.022^{* * *} \\
{[0.007]}\end{array}$ & $\begin{array}{c}0.023^{* * *} \\
{[0.007]}\end{array}$ & $\begin{array}{c}0.002 \\
{[0.006]}\end{array}$ & $\begin{array}{c}0.002 \\
{[0.006]}\end{array}$ \\
\hline HH Income irt $^{2}$ & $\begin{array}{c}-0.002^{* * *} \\
{[0.001]}\end{array}$ & $\begin{array}{c}-0.002^{* * *} \\
{[0.001]}\end{array}$ & $\begin{array}{c}-0.002^{* * *} \\
{[0.001]}\end{array}$ & $\begin{array}{c}-0.002^{* * * *} \\
{[0.001]}\end{array}$ & $\begin{array}{l}-0.000 \\
{[0.000]}\end{array}$ & $\begin{array}{l}-0.000 \\
{[0.000]}\end{array}$ \\
\hline Num. Old irt & $\begin{array}{c}-0.058^{* * *} * \\
{[0.016]}\end{array}$ & $\begin{array}{c}-0.059^{* * *} \\
{[0.016]}\end{array}$ & $\begin{array}{c}-0.059^{* * *} * \\
{[0.018]}\end{array}$ & $\begin{array}{c}-0.060^{* * *} * \\
{[0.018]}\end{array}$ & $\begin{array}{l}-0.003 \\
{[0.008]}\end{array}$ & $\begin{array}{l}-0.004 \\
{[0.008]}\end{array}$ \\
\hline Constant & $\begin{array}{c}0.233 \\
{[0.165]}\end{array}$ & $\begin{array}{c}0.293 \\
{[0.220]}\end{array}$ & $\begin{array}{c}0.354 \\
{[0.241]}\end{array}$ & $\begin{array}{c}0.430 \\
{[0.287]}\end{array}$ & $\begin{array}{l}-0.057 \\
{[0.284]}\end{array}$ & $\begin{array}{l}-0.082 \\
{[0.296]}\end{array}$ \\
\hline Obs. & 27,759 & 27,759 & 21,993 & 21,993 & 9,223 & 9,223 \\
\hline $\mathrm{R}^{2}$ & 0.223 & 0.220 & 0.237 & 0.233 & 0.070 & 0.068 \\
\hline F-Stat & . & 14.46 & . & 14.14 & . & 21.54 \\
\hline Control & yes & yes & yes & yes & yes & yes \\
\hline Region \& year FE & yes & yes & yes & yes & yes & yes \\
\hline $\begin{array}{l}\ddagger \text { Linear probabilit } \\
\text { is employed. } \operatorname{Pr}( \\
90^{\text {th }} \text { percentile o } \\
\text { ferent regression. } \\
\text { errors are cluster } \\
\text { Kleibergen-Paap } \\
\text { pation rate. All: } \\
\text { sample of natives } \\
\text { household service }\end{array}$ & $\begin{array}{l}\text { 1. Depende } \\
90^{\text {th }} \text { pct: d } \\
\text { distributio } \\
\text { cance level: } \\
\text { gional X y } \\
\text { istic. Regi } \\
\text { of all nati } \\
\text { ed women. }\end{array}$ & $\begin{array}{l}\text { variables } \\
\text { nmy takes } \\
\text { (by count } \\
0.10>\text { p-va } \\
\text { r level, an } \\
\text { al control } \\
\text { s women. } \\
\text { nsk NS: }\end{array}$ & $\begin{array}{l}\text { Part.: du } \\
\text { alue one i } \\
\text { and skill } \\
\text { e, } * * 0.05 \\
\text { are repor } \\
\text { nclude ur } \\
\text { killed: sa } \\
\text { ple of na }\end{array}$ & $\begin{array}{l}\text { y takes v } \\
\text { individu } \\
\text { el). Each } \\
\text {-value, } * * * \\
\text { in square } \\
\text { ployment } \\
\text { le of nati } \\
\text { s unskillec }\end{array}$ & $\begin{array}{l}\text { le one if } \\
\text { declare t } \\
\text { olumn res } \\
.01>\mathrm{p} \text {-va } \\
\text { brackets. } \\
\text { te, and } \mathrm{f} \\
\text { skilled } \\
\text { women no }\end{array}$ & $\begin{array}{l}\text { e individua } \\
\text { work above } \\
\text { esents a dif- } \\
\text { e. Standard } \\
\text {-Stat is the } \\
\text { hale partici- } \\
\text { men. Unsk } \\
\text { employed in }\end{array}$ \\
\hline
\end{tabular}

Male - One of the implicit assumptions of our analysis is that women take care of household management and household goods' production. Then, a reduction in the prices of household services leads women to substitute their time in domestic activities by increasing their labour supply. Conversely, men have a negligible amount of household duties. If variations in the regional concentration of unskilled migrants identify changes in the prices of household services, the presence of migrants should not affect male's labour supply given their different constraints. ${ }^{45}$

To test this hypothesis, we re-estimate Eq. 9 and Eq. 10 on a sample of native men aged from 22 to $45 .{ }^{46}$ Table 8 reports the estimation results. Similarly to the previous test, we control the robustness of our main findings, i.e., the participation rate of low-skilled and the probability of high-skilled to work longer hours (fixing the threshold at the $90^{t h}$ percentile). It is straightforward to observe that the coefficient of Migr. Services $s_{r t}$ is never significant for all the specifications. Variations in the regional concentration of migrants employed in

\footnotetext{
${ }^{45}$ We can reasonably state that a man face a different maximization problem, given that household goods' production does not enter in his utility function.

${ }^{46}$ We include men who are married, cohabitant with partners, or single as head of the household, and who are not enrolled in school. We do not include men that live with parents, or in army. We eliminate from the sample outliers by excluding observations above the $99^{t h}$ percentile of households' income, wage, and worked hours distributions (by country).
} 
household service sector do not affect the labour supply of native men (both at the intensive and extensive margins). Besides, the effects of control variables ${ }^{47}$ differ by gender: marital status has a positive effect on men's participation rates (columns 1-4), while the negative effect of children almost disappears. To conclude, estimation results support both the validity of our assumption (i.e., women spend time in household production ), and the existence of a price mechanism that affects women's time allocation between household activities and labour.

Table 8: Native male labour supply - intensive and extensive margins..$^{\ddagger}$.

\begin{tabular}{|c|c|c|c|c|c|c|}
\hline & $\begin{array}{c}(1) \\
\text { Unsk } \\
\text { Part. } \\
\text { OLS }\end{array}$ & $\begin{array}{c}(2) \\
\text { Unsk. } \\
\text { Part. } \\
\text { IV }\end{array}$ & $\begin{array}{c}(3) \\
\text { Unsk. NS } \\
\text { Part. } \\
\text { OLS }\end{array}$ & $\begin{array}{c}(4) \\
\text { Unsk. NS } \\
\text { Part. } \\
\text { IV }\end{array}$ & $\begin{array}{c}(5) \\
\text { Skilled } \\
\operatorname{Pr}\left(\text { Hours } \geq 90^{t h}\right) \\
\text { OLS }\end{array}$ & $\begin{array}{c}(6) \\
\text { Skilled } \\
\operatorname{Pr}\left(\text { Hours } \geq 90^{t h}\right) \\
\text { IV }\end{array}$ \\
\hline Migr. service $_{r t}$ & $\begin{array}{c}0.606 \\
{[0.510]}\end{array}$ & $\begin{array}{c}1.104 \\
{[1.456]}\end{array}$ & $\begin{array}{c}0.693 \\
{[0.594]}\end{array}$ & $\begin{array}{c}1.291 \\
{[1.694]}\end{array}$ & $\begin{array}{c}1.579 \\
{[1.237]}\end{array}$ & $\begin{array}{c}4.017 \\
{[3.616]}\end{array}$ \\
\hline Age $_{i r t}$ & $\begin{array}{c}0.020^{* * *} \\
{[0.008]}\end{array}$ & $\begin{array}{c}0.020^{* * *} \\
{[0.007]}\end{array}$ & $\begin{array}{c}0.021 * * \\
{[0.008]}\end{array}$ & $\begin{array}{c}0.021 * * * 0.017 \\
{[0.008]}\end{array}$ & $\begin{array}{c}0.017 \\
{[0.019]}\end{array}$ & {$[0.019]$} \\
\hline $\operatorname{Age}^{2}{ }_{i r t}$ & $\begin{array}{c}-0.000^{* * *} * \\
{[0.000]}\end{array}$ & $\begin{array}{c}-0.000 * * * \\
{[0.000]}\end{array}$ & $\begin{array}{c}-0.000 * * * \\
{[0.000]}\end{array}$ & $\begin{array}{c}-0.000^{* * *} \\
{[0.000]}\end{array}$ & $\begin{array}{l}-0.000 \\
{[0.000]}\end{array}$ & $\begin{array}{l}-0.000 \\
{[0.000]}\end{array}$ \\
\hline Child $(01)_{i r t}$ & $\begin{array}{l}-0.019 \\
{[0.012]}\end{array}$ & $\begin{array}{l}-0.019 \\
{[0.012]}\end{array}$ & $\begin{array}{l}-0.017 \\
{[0.013]}\end{array}$ & $\begin{array}{l}-0.017 \\
{[0.013]}\end{array}$ & $\begin{array}{c}-0.033^{* *} \\
{[0.016]}\end{array}$ & $\begin{array}{c}-0.032^{* *} \\
{[0.016]}\end{array}$ \\
\hline Child $(24)_{i r t}$ & $\begin{array}{c}-0.028^{* *} \\
{[0.012]}\end{array}$ & $\begin{array}{c}-0.028^{* *} \\
{[0.012]}\end{array}$ & $\begin{array}{c}-0.032^{* *} \\
{[0.014]}\end{array}$ & $\begin{array}{c}-0.032^{* *} \\
{[0.014]}\end{array}$ & $\begin{array}{c}0.024 \\
{[0.023]}\end{array}$ & $\begin{array}{c}0.025 \\
{[0.023]}\end{array}$ \\
\hline Child(57) $)_{i r t}$ & $\begin{array}{c}-0.020^{*} \\
{[0.011]}\end{array}$ & $\begin{array}{c}-0.020^{*} \\
{[0.011]}\end{array}$ & $\begin{array}{c}-0.024^{* *} \\
{[0.012]}\end{array}$ & $\begin{array}{c}-0.024^{* *} \\
{[0.012]}\end{array}$ & $\begin{array}{c}-0.047^{* * * *} \\
{[0.018]}\end{array}$ & $\begin{array}{c}-0.046^{* * * *} \\
{[0.018]}\end{array}$ \\
\hline Marit. Status $i r t$ & $\begin{array}{c}0.050^{* * *} * \\
{[0.009]}\end{array}$ & $\begin{array}{c}0.050^{* * *} * \\
{[0.009]}\end{array}$ & $\begin{array}{c}0.058^{* * *} \\
{[0.010]}\end{array}$ & $\begin{array}{c}0.058^{* * *} \\
{[0.010]}\end{array}$ & $\begin{array}{c}0.003 \\
{[0.022]}\end{array}$ & $\begin{array}{c}0.002 \\
{[0.021]}\end{array}$ \\
\hline $\mathrm{HH}_{\text {Income }_{i r t}}$ & $\begin{array}{c}0.004 \\
{[0.003]}\end{array}$ & $\begin{array}{c}0.004 \\
{[0.003]}\end{array}$ & $\begin{array}{c}0.005 \\
{[0.003]}\end{array}$ & $\begin{array}{c}0.005 \\
{[0.003]}\end{array}$ & $\begin{array}{c}0.005 \\
{[0.011]}\end{array}$ & $\begin{array}{c}0.005 \\
{[0.008]}\end{array}$ \\
\hline $\mathrm{HH} \mathrm{Income}^{2}{ }_{i r t}$ & $\begin{array}{c}-0.001^{* * *} * \\
{[0.000]}\end{array}$ & $\begin{array}{c}-0.001 * * * \\
{[0.000]}\end{array}$ & $\begin{array}{c}-0.001 * * * \\
{[0.000]}\end{array}$ & $\begin{array}{c}-0.001^{* * *} * \\
{[0.000]}\end{array}$ & $\begin{array}{l}-0.000 \\
{[0.001]}\end{array}$ & $\begin{array}{l}-0.000 \\
{[0.001]}\end{array}$ \\
\hline Num. Old irt & $\begin{array}{l}0.017^{*} \\
{[0.009]}\end{array}$ & $\begin{array}{l}0.017^{*} \\
{[0.009]}\end{array}$ & $\begin{array}{l}0.020^{*} \\
{[0.011]}\end{array}$ & $\begin{array}{l}0.020^{*} \\
{[0.011]}\end{array}$ & $\begin{array}{c}-0.034^{*} \\
{[0.019]}\end{array}$ & $\begin{array}{c}-0.034^{*} \\
{[0.018]}\end{array}$ \\
\hline Constant & $\begin{array}{c}0.561^{* * *} \\
{[0.192]}\end{array}$ & $\begin{array}{c}0.538^{* * *} * \\
{[0.190]}\end{array}$ & $\begin{array}{c}0.540^{* *} \\
{[0.219]}\end{array}$ & $\begin{array}{c}0.512^{* *} * \\
{[0.218]}\end{array}$ & $\begin{array}{l}-0.120 \\
{[0.359]}\end{array}$ & $\begin{array}{l}-0.224 \\
{[0.376]}\end{array}$ \\
\hline Obs. & 10,804 & 10,804 & 9,589 & 9,589 & 5,444 & 5,444 \\
\hline Control & yes & yes & yes & yes & yes & yes \\
\hline Region \& year FE & yes & yes & yes & yes & yes & yes \\
\hline $\mathrm{R}^{2}$ & 0.061 & 0.061 & 0.064 & 0.064 & 0.037 & 0.036 \\
\hline F-Stat & . & 10.51 & . & 10.46 & . & 24.73 \\
\hline \multicolumn{7}{|c|}{$\begin{array}{l}\text { ₹ Linear probability model. Dependent variables. Part.: dummy takes value one if the individual is employed. } \\
\operatorname{Pr}\left(\text { Hours } \geq 90^{\text {th }} \text { pct): dummy takes value one if an individuals declare to work above } 90^{\text {th }} \text { percentile of hours }\right. \\
\text { distribution (by country and skill level). Pr }(\text { Hours } \geq 50): \text { dummy takes value one if an individuals declare to } \\
\text { work more than } 50 \text { hours per week. Each column represents a different regression. Estimation sample consists of } \\
\text { native men with age } 22-45 \text {. Significance level: } * 0.10>\text { p-value } * * 0.05>\text { p-value*** } 0.01>\text { p-value. Standard errors } \\
\text { are clustered at regional X year level, and are reported in squared brackets. F-Stat is the Kleibergen-Paap } r k \\
\text { statistic. Regional controls include unemployment rate, and male participation rate. All: sample of all natives } \\
\text { man. Unsk: sample of unskilled native man. }\end{array}$} \\
\hline
\end{tabular}

Services' Price - In line with previous empirical evidences, we assume that the prices of household services are lower in areas with a higher concentration of unskilled migrants. In the following, we test this assumption in our data. In this case, we use as a proxy of prices the individual wages. We estimate the impact of migrants on the wage of unskilled workers in household services. ${ }^{48}$

Several control variables are included. First, we consider regional and year fixed effects, as well as regional unemployment rate. Furthermore, we add a gender dummy and a foreign born dummy jointly with the usual

\footnotetext{
${ }^{47}$ Notice that variable $H H$ Income $_{i r t}$ is defined as the total household income minus man's gross earnings.

${ }^{48}$ The dependent variable is the log of gross annual earnings of unskilled workers employed in household services, in US dollar (PPP, 2000).
} 
individual controls (age, age squared, marital status., etc.). ${ }^{49}$ We test the existence of an empirical relationship both with OLS and IV approaches. Results are reported in Table 9.

The IV model in column 2 shows a negative effect of the regional concentration of unskilled migrants in household services on the average gross wage of unskilled workers in those sectors. The inclusion of individual controls (columns 3 and 4) does not change the sign of the estimated coefficient. In the last two columns, we excluded foreign born workers from the estimation sample, given that CNEF does not report information about migrants for UK and USA. Again, we find that wages of unskilled workers in services are negatively affected by the regional concentration of migrants. In light of these results, we are quite confident that the variable Migr. services is able to identify the variability of prices in household service sector across regions.

\begin{tabular}{|c|c|c|c|c|c|c|}
\hline & (1) & (2) & (3) & (4) & (5) & (6) \\
\hline & OLS & IV & OLS & IV & OLS & IV \\
\hline & All & All & All & All & Natives & Natives \\
\hline \multirow{2}{*}{ Migr. service ${ }_{r c t}$} & -3.561 & $-20.201^{* * *}$ & -3.427 & $-15.081^{* *}$ & -3.835 & $-19.409^{* *}$ \\
\hline & {$[2.710]$} & {$[7.806]$} & {$[2.204]$} & {$[7.329]$} & {$[2.454]$} & {$[9.751]$} \\
\hline \multirow[t]{2}{*}{ Constant } & $8.961 * * *$ & $9.219 * * *$ & $5.770 * * *$ & $5.488 * * *$ & $6.370 * * *$ & $6.123^{* * *}$ \\
\hline & {$[0.206]$} & {$[0.203]$} & {$[0.608]$} & {$[0.614]$} & {$[0.623]$} & {$[0.666]$} \\
\hline Obs. & 11,148 & 11,148 & 11,134 & 11,134 & 10,098 & 10,098 \\
\hline R-squared & 0.037 & 0.033 & 0.275 & 0.273 & 0.283 & 0.281 \\
\hline Indiv. controls & no & no & yes & yes & yes & yes \\
\hline Fixed effects & regional/year & regional/year & regional/year & regional/year & regional/year & regional/year \\
\hline F-Stat & . & 21.69 & . & 19.08 & . & 12.35 \\
\hline \multicolumn{7}{|c|}{$\begin{array}{l}\mp \text { Linear probability model. Dependent variable is the log of gross annual earnings of unskilled worker employed } \\
\text { household services in US dollar (PPP, 2000). Each observation represents an individual from national surveys. } \\
\text { Immigration intensity is the ratio of unskilled migrants in household services to total labour force. Regional } \\
\text { and year year fixed effects are included. Individual controls are: foreign born dummy, gender, age, age squared, } \\
\text { marital status, dummy for children with age } 0-12-45-7 \text {, household gross earnings minus women earnings and } \\
\text { its squared term, number of elderly people in the household. In column }(2) \text { and (4), we report results from } \\
\text { instrumental variable model. F-Stat is the Kleibergen-Paap rk statistic Significance level: *0.10>p-value } * * \\
0.05>\text { p-value*** } 0.01>\text { p-value. Standard errors are clustered at regional X year level, and are reported in } \\
\text { squared brackets. }\end{array}$} \\
\hline
\end{tabular}

\section{Family policy and female labour participation}

The main goal of this section is to understand whether unskilled immigration in services is a substitute for social policies, i.e., policies which aim to combine work and family responsibilities, and which especially target women in fertility age.

In the previous sections, we showed that an increase in the supply of household services and their prices' reduction (due to migrants) leads to an improvement in the environmental conditions that affect women's labour market decisions. In particular, we found that the share of unskilled immigrants working in services in a given labour regional market is positively associated with the probability of native women to increase their labour supply at the intensive margin, if skilled, and at the extensive margin, if unskilled.

Thanks to the cross-national dimension of our data, in this section we want to exploit the institutional

\footnotetext{
${ }^{49}$ Notice that here we consider both male and female, and migrants and natives.
} 
variability between countries to understand whether the effect of unskilled immigration on female labour supply is particularly relevant in countries where family social policies are not very effective, and whether this effect is stronger for skilled or unskilled native women.

Recent studies show that differences in family social policies account for a non-negligible percentage of the differences among OECD countries in women's labour force participation (Blau and Kahn, 2013; Del Boca et al., 2009; Del Boca and Sauer, 2009). In particular, it has been shown that the impact of family policies differs with women's education levels. The labour market offers more opportunities for high skilled women who are more likely to work irrespective of the characteristics of the environment. Instead less educated women face higher costs of participation and are more sensitive to changes in income and prices. In such a framework, social policies have a stronger impact on labour market decisions of low-skilled women (Blau and Kahn, 2013; Del Boca et al., 2009).

Countries differ in family social policies depending on the availability of part-time work opportunities, childcare services (e.g., affordable pre-primary education), allowance and facilities for families (e.g., tax benefits for families with kids), or labour market regulation (e.g., parental leave).

Even if, in general, the literature show a positive effect of social policies on female labour supply, the impact of each social policy indicator can have an ambiguous effect on the female labour decision. For instance, parental leaves give the entitlement to come back to work after taking the leave, thus favouring female labour supply. On the other hand, they may encourage women to stay out of the labour force for a longer period, thus deterring employers to hire women. The same holds for family allowance: cash benefits might have a negative effect on female labour force participation especially in the case of generous allowance for poor households.

Of course the country-specific policy context, the specific cultural, and institutional environment might be particularly important to asses the effect of each specific policy indicator. Then, quantitative data are not sufficiently informative to classify countries in terms of effectiveness of family policies, and they should be integrated with qualitative information.

For this purpose, we consider a new and comprehensive score index developed by the Bertelsmann Foundantion to classify countries in terms of different social policies. The Sustainable Governance Indicators (SGI) is a cross-national survey of governance systems for the OECD countries (collected in 2009 and 2011), with the aim to support the realization of sustainable policies. ${ }^{50}$ In particular, we consider the specific index component for family policy (Status Index) from the SGI 2009 edition $^{51}$, which combines qualitative and quantitative information. This index is particularly related to our research question, because it ideally wants to answer the question

\footnotetext{
${ }^{50}$ SGI are divided into two pillars: one pillar encompasses sustainable policy performance (Status Index), and the other comprises governance (Management Index). Status index accounts indicators for the quality of democracy, and economic performances in four areas: (i) economy and employment, (ii) social affairs, (iii) security, (iv) resources. Instead, the management index examines how effective governments are in directing and implementing appropriate policies. For a detailed description of indices look at Novy et al. (2009).

${ }^{51}$ The SGI 2009 edition refers to the period of investigation January 2005 to March 2007.
} 
"do family policies enable women to combine parenting and employment?". The family index is constructed with one qualitative indicator (based on the assessments of SGI country experts), and several quantitative indicators to measure the coverage of family policy (child care density, child poverty, fertility rate, spending on family policy). The qualitative assessment refers to the period of investigation as a whole (2005 to 2007): the scoring scale ranges from 1 (worst) to 10 (best). Quantitative data are collected from public statistical sources (OECD, Eurostat etc.). A linear transformation is used to convert the quantitative raw data on a scale from 1 to 10; for each period of investigation the most recent quantitative data is used. Then, the aggregate score for family policy is defined as the arithmetic mean of the qualitative indicator (expert assessment) counting one half, and the arithmetic mean of the four quantitative indicators (the other half).

SGI rank countries into four groups according to the distribution of their family policy index. ${ }^{52}$ Following this classification, we divide our country sample into two groups: high-supportive countries (Australia and UK which belongs to the upper medium group (between 75th and 50th percentile) of index distribution), and low-supportive countries (Germany, USA, and Switzerland which are below the median of the distribution). ${ }^{5354}$

Table 10 shows for the two country groups the impact of unskilled migrants on the probability to enter the labour market for unskilled native women, and on the probability to work longer hours (fixing the threshold at the $90^{\text {th }}$ percentile).

Regarding the skilled native women, we observe that the regional concentration of migrants has a positive and significant effect on the decision to work longer hours only in low-supportive countries. This is quite intuitive: more educated women are less sensitive to the characteristics of the environment, and only women at the top of the distribution which are probably employed in occupations that require long hours, make use of services provided by low-skilled immigrants only when the environment is not sufficiently flexible and supportive for their career.

Focusing on unskilled natives, the regional concentration of migrants has a positive and significant effect on the probability to enter the labour force both in low and in high supportive countries, obviously with a stronger effect in low-supportive ones. As less educated women are more influenced by the availability of part-time jobs, childcare, optional parental leave and child allowance, when these services are not sufficiently developed, immigrants become of particular importance for natives' labour market decision. This suggests that immigration in services might be a substitute for social policies when the government support is rather low. However, immigrants have also a positive impact in high supporting countries.

To better investigate to which extent immigrants favour the participation to the labour market of the

\footnotetext{
${ }^{52}$ Top group, upper middle group, lower middle group, and bottom group.

${ }^{53}$ In details, UK gets a score of 7.4, Australia a score of 7.1, Germany a score of 6.3 , USA a score of 5.6, and Switzerland a score of 4.5. Norway and Sweden are on the top of the ranking for family index with a score of 9.1 and 8.9, respectively. For more details, look Appendix B.

${ }^{54}$ We make two assumptions. At first, the 2009 edition for SGI is a reliable indicator for family policies from 2001 to 2005 . Note that 2009 SGI edition relies on quantitative data from 2005 to 2007. Second, we assume that the ranking does not change over the period of analysis.
} 
Table 10: Family policy

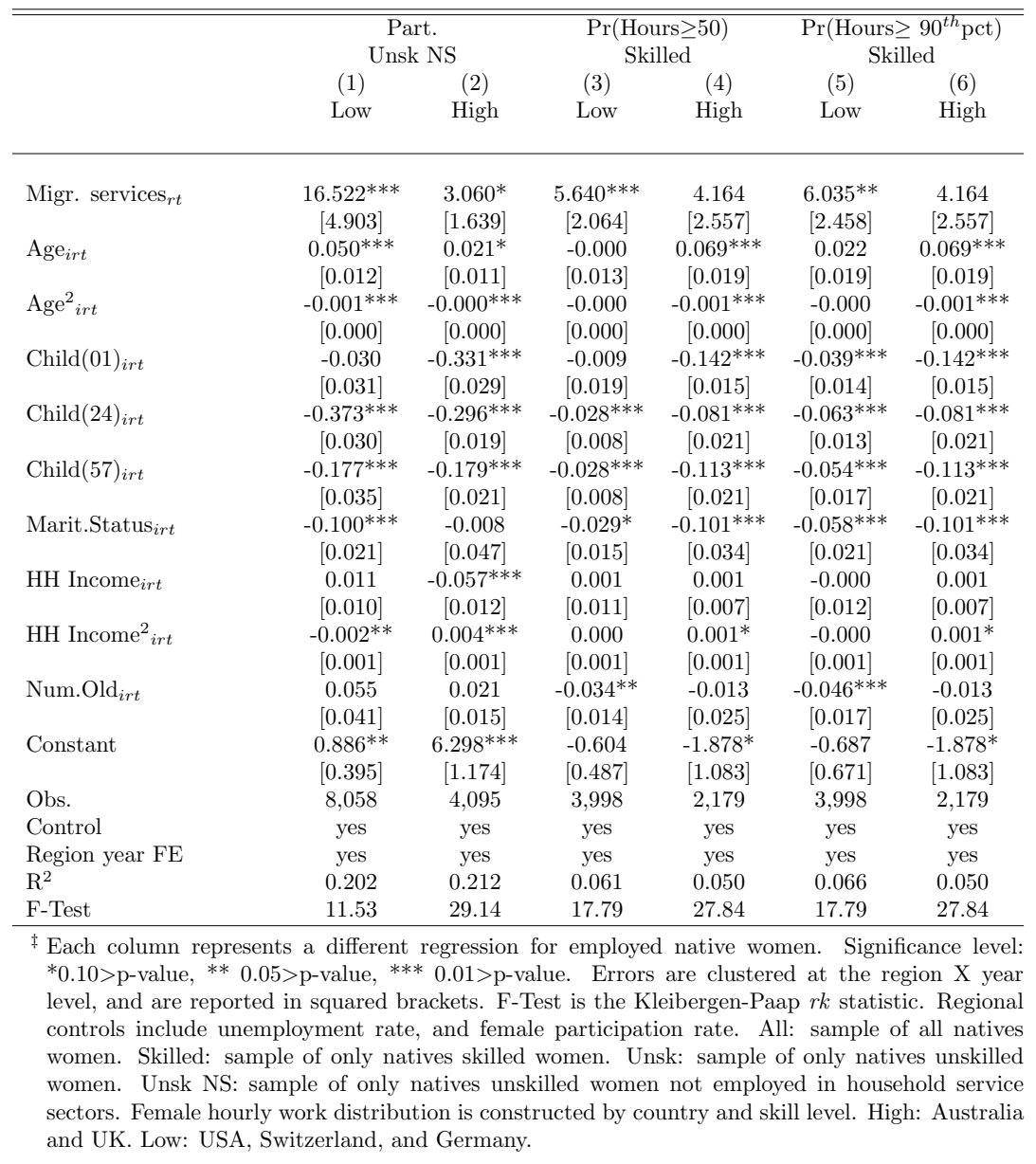

unskilled native (Table 10), we consider the alternatives faced by unskilled native women between unemployment (0), and part-time or full-time employment (1).

Table 11 and Table 12 display estimation results for low and high supportive countries, respectively. In low supportive countries, the effect of migrants is positive and significant for both the decision to become full-time (significant at 10\%) and part-time employed (significant at 1\%) by unskilled native women. However, the effect of the main explanatory variable on part-time employment is much stronger (columns 5 and 6). This again is in line with the more recent literature on social policies. According to Blau and Kahn (2013), for instance, these policies appear to encourage part-time work and employment in lower level positions.

Looking at high supportive countries, the effect of migrants is positive and statistically significant only for the decision to become a part-time worker. Only unskilled native women (not employed in services) are positively affected by an increase in the concentration of immigrants (Table 12, column 6). However, migrants' labour supply in household services has a much weaker impact on the participation rate in high supportive countries than in low supporting countries. Compared to Table 11, the coefficient is smaller. An increase of $10 \%$ in Migr. Services st $_{\text {in }}$ high supportive countries leads to an increase by 1.14 percentage point in the 
probability to be part-time employed, whereas an increase of the same amount in low supportive countries raises the probability to become part-time employed by 3.55 percentage point. In line with previous findings, the impact of migrants' regional concentration is stronger for women not employed in household service sector.

It is worthwhile to observe that, in high supportive countries, marital status and age do not affect the employment decision of native women. Conversely, in low supportive countries marital status is associated with a lower probability to be employed (both part-time and full-time). Moreover, the presence of children in the household continues to show a negative impact, but the coefficients for high supportive countries are smaller than their counterparts in low supportive countries (for the age brackets 2-4). This suggests that in countries with effective family policy, traditional obstacles to women's labour force participation are less binding.

\begin{tabular}{|c|c|c|c|c|}
\hline & $\begin{array}{c}\text { (1) } \\
\text { Unsk. } \\
\text { Full-time }\end{array}$ & $\begin{array}{c}(2) \\
\text { Unsk. NS } \\
\text { Full-time }\end{array}$ & $\begin{array}{c}\text { (3) } \\
\text { Unsk. } \\
\text { Part-time }\end{array}$ & $\begin{array}{c}\text { (4) } \\
\text { Unsk. NS } \\
\text { Part-time }\end{array}$ \\
\hline Migr. services ${ }_{r t}$ & $\begin{array}{l}5.843^{*} \\
{[3.479]}\end{array}$ & $\begin{array}{l}6.080 * \\
{[3.530]}\end{array}$ & $\begin{array}{c}18.777^{* * *} \\
{[5.594]}\end{array}$ & $\begin{array}{c}25.398^{* * *} \\
{[8.073]}\end{array}$ \\
\hline $\operatorname{Age}_{i r t}$ & $\begin{array}{c}0.042^{* * *} \\
{[0.011]}\end{array}$ & $\begin{array}{c}0.042^{* * *} \\
{[0.014]}\end{array}$ & $\begin{array}{c}0.057^{* * *} \\
{[0.019]}\end{array}$ & $\begin{array}{c}0.073^{* * *} \\
{[0.022]}\end{array}$ \\
\hline $\mathrm{Age}^{2}{ }_{i r t}$ & $\begin{array}{c}-0.001 * * * \\
{[0.000]}\end{array}$ & $\begin{array}{c}-0.001^{* * * *} \\
{[0.000]}\end{array}$ & $\begin{array}{c}-0.001^{* * *} * \\
{[0.000]}\end{array}$ & $\begin{array}{c}-0.001 * * * \\
{[0.000]}\end{array}$ \\
\hline Child $(0-1)_{i r t}$ & $\begin{array}{c}-0.256^{* * *} \\
{[0.035]}\end{array}$ & $\begin{array}{c}-0.234^{* * * *} \\
{[0.038]}\end{array}$ & $\begin{array}{l}-0.018 \\
{[0.034]}\end{array}$ & $\begin{array}{c}0.049 \\
{[0.035]}\end{array}$ \\
\hline Child $(2-4)_{i r t}$ & $\begin{array}{c}-0.477^{* * *} \\
{[0.034]}\end{array}$ & $\begin{array}{c}-0.451^{* * * *} \\
{[0.036]}\end{array}$ & $\begin{array}{c}-0.311^{* * * *} \\
{[0.029]}\end{array}$ & $\begin{array}{c}-0.329^{* * *} \\
{[0.035]}\end{array}$ \\
\hline Child (5-7) irt & $\begin{array}{c}-0.327^{* * *} \\
{[0.025]}\end{array}$ & $\begin{array}{c}-0.325^{* * *} \\
{[0.024]}\end{array}$ & $\begin{array}{c}-0.101^{* * *} \\
{[0.035]}\end{array}$ & $\begin{array}{c}-0.121^{* * *} \\
{[0.038]}\end{array}$ \\
\hline Marit. Status $_{i r t}$ & $\begin{array}{c}-0.133^{* * *} \\
{[0.021]}\end{array}$ & $\begin{array}{c}-0.166^{* * *} \\
{[0.028]}\end{array}$ & $\begin{array}{c}-0.085^{* * *} \\
{[0.027]}\end{array}$ & $\begin{array}{c}-0.096 * * * \\
{[0.034]}\end{array}$ \\
\hline HH Income $_{i r t}$ & $\begin{array}{c}0.011 \\
{[0.010]}\end{array}$ & $\begin{array}{c}0.011 \\
{[0.013]}\end{array}$ & $\begin{array}{c}0.002 \\
{[0.020]}\end{array}$ & $\begin{array}{c}0.001 \\
{[0.024]}\end{array}$ \\
\hline HH Income $^{2}{ }_{i r t} *$ & $\begin{array}{c}-0.002^{* * *} \\
{[0.001]}\end{array}$ & $\begin{array}{c}-0.002^{* *} \\
{[0.001]}\end{array}$ & $\begin{array}{l}-0.001 \\
{[0.001]}\end{array}$ & $\begin{array}{l}-0.001 \\
{[0.002]}\end{array}$ \\
\hline Num. Old $_{i r t}$ & $\begin{array}{c}0.080 \\
{[0.050]}\end{array}$ & $\begin{array}{l}0.095^{*} \\
{[0.056]}\end{array}$ & $\begin{array}{c}0.011 \\
{[0.045]}\end{array}$ & $\begin{array}{l}0.007 \\
{[0.051]}\end{array}$ \\
\hline Constant & $\begin{array}{c}0.890^{* *} \\
{[0.408]}\end{array}$ & $\begin{array}{l}0.800^{*} \\
{[0.453]}\end{array}$ & $\begin{array}{c}1.198^{* *} \\
{[0.535]}\end{array}$ & $\begin{array}{l}1.144^{*} \\
{[0.669]}\end{array}$ \\
\hline $\begin{array}{l}\text { Obs. } \\
\mathrm{R}^{2} \\
\text { F-Stat }\end{array}$ & $\begin{array}{l}6,047 \\
0.428 \\
11.19\end{array}$ & $\begin{array}{l}4,960 \\
0.435 \\
11.52\end{array}$ & $\begin{array}{l}0.108 \\
10.42\end{array}$ & $\begin{array}{l}5,228 \\
0.115 \\
10.02\end{array}$ \\
\hline \multicolumn{5}{|c|}{$\begin{array}{l}\ddagger \text { Linear probability model. Each column represents a different re- } \\
\text { gression. Immigration intensity is the ratio of unskilled migrants } \\
\text { in household services to total labour force. Regional and year year } \\
\text { fixed effects are included. Standard errors are clustered at regional } \\
\text { X year level, and are reported in squared brackets. F-Stat is the } \\
\text { Kleibergen-Paap rk statistic. Regional controls include unemploy- } \\
\text { ment rate, and female participation rate. All: sample of all natives } \\
\text { women. Skilled: sample of natives skilled women. Unsk: sample } \\
\text { of natives unskilled women. Unsk NS: sample of natives unskilled } \\
\text { women not employed in household service sectors. }\end{array}$} \\
\hline
\end{tabular}


Table 12: Extensive margin of labour supply. Part-time and full-time, high supportive countries

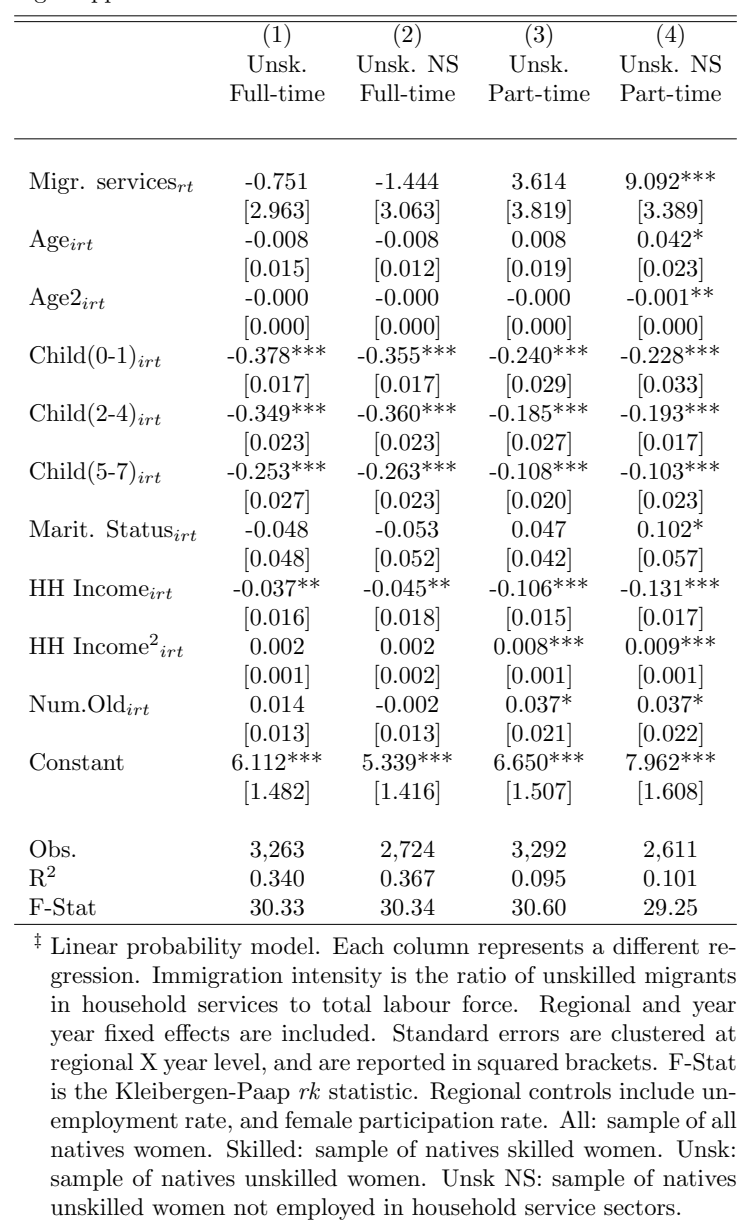

\section{Conclusions}

After presenting and discussing a model of individual choice with household production, we have estimated two reduced-form models to test its main predictions. With the first, we have evaluated the effect of unskilled migrants in services on the hours of work supplied (i.e., at the intensive margin). With the second, the impact on female labour participation (i.e., at the extensive margin). We have restricted our analysis to native women aged 22-45, living apart from their parents. Our results indicate that the presence of unskilled migrants in services positively affects the natives labour supply. In particular, unskilled migrants induce an increase in labour market participation for native, unskilled women, and the supply of hours of labour for skilled natives. This last result is coherent with the one obtained by Cortés and Tessada (2011), where an increase in migration intensity raises the probability to work more than 50 hour per week by skilled natives. An entirely novel empirical finding is the one concerning the effect at the extensive margin for unskilled native women. In particular, we have found that an average increase of $1 \%$ in unskilled migrants intensity increases by 0.04 percentage point the probability to 
work more than 50 hour per week by skilled women. It also increases of 0.14 percentage points the probability to participate to labour market for unskilled women. Both results are particularly strong for women in households with kids. The results are robust to different sample compositions and identification tests. Finally, we have shown that the impact of unskilled migrant in services is stronger in countries which are less supportive to families, in terms of policy interventions. This suggests that unskilled migration in services might be, in a way, a substitute for social policies.

\section{References}

Barone, G. and Mocetti, S. (2011). With a little help from abroad: The effect of low-skilled immigration on the female labour supply. Labour Economics, Vol.18(5): 664-675.

Blau, F. and Kahn, L. (2013). Female labor supply: Why is the us falling behind? The American Economic Review, Vol.103(3): 251-256.

Borjas, G. (2006). Native internal migration and the labor market impact of immigration. Journal of Human Resources, Vol.41(2).

Brice, B., Buck, N., and E., P.-L. (2010). British Household Panel Survey User Manual Volume A: Introduction, Technical Report and Appendices.

Brücker, H. and Jahn, E. (2011). Migration and wage setting: Reassessing the labor market effects of migration. Scandinavian Journal of Economics, Vol.113(2): 286-317.

Card, D. (2001). Immigrant inflows, native outflows, and the local labor market impacts of higher immigration. Journal of Labor Economics, Vol.19(1): 22-64.

Card, D. and Lewis, E. (2007). The diffusion of mexican immigrants during the 1990s: explanations and impact. In Mexican Immigration to the United States, NBER Chapters, pages 193-228. National Bureau of Economic Research.

Cortés, P. (2008). The effect of low-skilled immigration on us prices: Evidence from CPI data. Journal of Political Economy, Vol.116(3): 381-422.

Cortés, P. and Tessada, S. (2011). Low-skilled immigration and the labor supply of highly skilled women. American Economic Journal: Applied Economics, Vol.3(3): 88-123.

D'Amuri, F., Ottaviano, G., and Peri, G. (2010). The labour market impact of immigration in western germany in the 1990s. European Economic Review, Vol.54(4): 550-570. 
Del Boca, D., Pasqua, S., and Pronzato, C. (2009). Motherhood and market work decisions in institutional context: a european perspective. Oxford Economic Papers, Vol.61(1): 147-171.

Del Boca, D. and Sauer, R. (2009). Life cycle employment and fertility across institutional environments. European Economic Review, Vol.53(1): 274-292.

Docquier, F., Ozden, C., and Peri, G. (2013). The labor market impact of immigration and emigration in OECD countries. Economic Journal (Accepted for publication).

Dustmann, C. and Theodoropoulos, N. (2010). Ethnic minority immigrants and their children in britain. Oxford Economic Papers, Vol.62(2): 209-233.

Farré, L., Gonzalez, L., and Ortega, F. (2011). Immigration, family responsibilities and the labor supply of skilled native women. The B.E. Journal of Economic Analysis E Policy, Vol.11(1).

Frattini, T. (2012). Immigration and prices in the UK. Technical Report mimeo.

Frick, J., Jenkins, S., Lillard, D., Lipps, O., and Wooden, M. (2012). The Cross-National Equivalent File (CNEF) and its member country household panel studies. Journal of Applied Social Science Studies, Vol.127(4): 627654.

Furtado, D. and Hock, H. (2010). Low skilled immigration and work-fertility trade-off among high skilled us natives. American Economic Review, Vol.100(2): 224-228.

Manacorda, M., Manning, A., and Wadsworth, J. (2012). The impact of immigration on the structure of male wages: Theory and evidence from britain. Journal of the European Economic Association, Vol.10(1): 120-151.

Novy, L., Kuhn, A., and Schraad-Tischler, D. (2009). Sustainable Governance Indicators 2009 Policy Performance and Executive Capacity in the OECD. Bertelsmann Stiftung.

Peri, G. and Sparber, C. (2009). Task specialization, immigration, and wages. American Economic Journal: Applied Economics, Vol.1(3): 135-169.

Peri, G. and Sparber, C. (2011). Assessing inherent model bias: An application to native displacement in response to immigration. Journal of Urban Economics, Vol.69(1): 82-91.

Ruggles, J., Trent, A., Genadek, K., Goeken, R., Schroeder, M., and Sobek, M. (2010). Integrated Public Use Microdata Series: Version 5.0 [Machine-readable database]. Minneapolis, MN.

Stock, J. and Yogo, M. (2002). Testing for weak instruments in linear iv regression. NBER Technical Working Papers 0284, National Bureau of Economic Research. 
Summerfield, M., Dunn, R., Freidin, S., Hahn, M., Ittak, P., Kecmanovic, M., Li, N., Macalalad, N., Watson, N., Wilkins, R., and Wooden, M. (2011). HILDA User Manual Release 10.

Wagner, G., Frick, J., and Schupp, J. (2012). The German Socio Economic Panel Study (SOEP) Scope, Evolution and Enhancements. Journal of Applied Social Science Studies, Vol.127(1): 139-169.

Zimmermann, K. (2009). Labor mobility and the integration of european labor markets. IZA Discussion Papers 3999, Institute for the Study of Labor (IZA). 


\section{A The model}

The assumptions on utility and production functions are:

1. $U(),. \Psi($.$) and \Phi($.$) are strictly concave, twice continuously differentiable, and increasing in all the choice variables.$ Additionally, they satisfy the (equivalent) of the Inada's condition.

2. $F(X, H)$ is concave and exhibits constant return to scale. ${ }^{55}$ Moreover, it is twice continuously differentiable, monotone and satisfies $\lim _{(X, H) \rightarrow(\bar{X}, 0)} \frac{1}{\frac{\partial F(.)}{\partial H}}=0$, for each $\bar{X}>0$. The marginal product of $X$ has the analogous property.

Under (1), it is easy to see that, at each strictly positive price vector, the optimal choice $(Y, \ell, R)$ is strictly positive.

Throughout the Appendix, we assume that the optimal solution of the utility maximization problem satisfies $n>0$.

\section{A.1 Cost minimization for household production}

Consider the optimization problem

$$
\min _{(X, H)} w H+p X \text { s.to } \bar{R}=F(X, H)
$$

for some given $\bar{R}$. With constant return to scale, we can write the cost function as $c(w, p) R$, where $c(w, p)$ is the "unit price" of household production for an individual with market wage $w$. By constant return to scale and Shepard's Lemma, the conditional demand functions are

$$
\begin{aligned}
H(w, p, \bar{R}) & \equiv h(w, p) \bar{R}=\frac{\partial c(.)}{\partial w} \bar{R} \\
X(w, p, \bar{R}) & \equiv x(w, p) \bar{R}=\frac{\partial c(.)}{\partial p} \bar{R}
\end{aligned}
$$

Evidently, $\left(\frac{\partial h(.)}{\partial w}, \frac{\partial x(.)}{\partial p}\right)<<0$ and, with two inputs, necessarily $\left(\frac{\partial h(.)}{\partial p}, \frac{\partial x(.)}{\partial w}\right)>>0$.

\section{A.2 Comparative statics of the labour supply}

By Shepard's Lemma and the assumption that $F($.$) has constant return to scale,$

$$
\begin{aligned}
\frac{\partial n}{\partial p} & \equiv-\frac{\partial \ell}{\partial p}-\frac{\partial H}{\partial p}-\frac{\partial H}{\partial R} \frac{\partial R}{\partial p}=-\frac{\partial \ell}{\partial p}-\frac{R(.) h(.)}{p}\left(\frac{\partial h}{\partial p} \frac{p}{h(.)}+\frac{p}{R} \frac{\partial R}{\partial p}\right) \\
\frac{\partial n}{\partial w} & \equiv-\frac{\partial \ell}{\partial w}-\frac{R(.) h(.)}{p}\left(\frac{\partial h}{\partial w} \frac{p}{h(.)}+\frac{p}{R} \frac{\partial R}{\partial w}\right),
\end{aligned}
$$

To analyse $\frac{\partial \ell}{\partial p}$ and $\frac{\partial R}{\partial p}$ (and $\frac{\partial \ell}{\partial w}, \frac{\partial R}{\partial w}$ ), let's rewrite $(V)$ in a simplified form. Since, by assumption, $n>0$, we can use the cost minimization problem (min) to obtain the unit cost of good $R$. Using this, and getting rid of the constraints

\footnotetext{
${ }^{55}$ Similar resuts might be obtained using a quasi-linear production function, as in Cortes and Tessada (2011).
} 
(1), (2) and (3a, 3b), we can rewrite $(V)$ as

$$
\max _{(\ell, R)} U(I+w-w \ell-c(.) R)+\psi \Psi(\ell)+\phi \Phi(\underline{R}+R),
$$

where, for future reference, we assume that the agent is endowed with a quantity $\underline{R}>0$ of household production output. When the optimal value has $R>0$, the optimal solution to $\left(V^{\prime}\right)$ is completely characterized by its first order conditions $(\mathrm{FOC})$

$$
F O C(\ell, R ; p, w, I, \underline{R})=\left[\begin{array}{c}
-\frac{\partial U}{\partial Y} w+\psi \frac{\partial \Psi}{\partial \ell} \\
-\frac{\partial U}{\partial Y} c(.)+\phi \frac{\partial \Phi}{\partial R}
\end{array}\right]=0 .
$$

By the implicit function theorem, $D_{(p, w, I)}(\ell(),. R())=.-\left[D_{(\ell, R)} F O C\right]^{-1}\left[D_{(p, w, I)} F O C\right]$. By direct computation,

$$
\begin{aligned}
\operatorname{det} D_{(\ell, R)} F O C & \equiv \operatorname{det}=\phi \frac{\partial^{2} U}{\partial Y^{2}} \frac{\partial^{2} \Phi}{\partial R^{2}} w^{2}+\phi \psi \frac{\partial^{2} \Phi}{\partial R^{2}} \frac{\partial^{2} \Psi}{\partial \ell^{2}}+\psi \frac{\partial^{2} U}{\partial Y^{2}} \frac{\partial^{2} \Psi}{\partial \ell^{2}} c(.)^{2}>0 \\
-\left[D_{(\ell, R)} F O C\right]^{-1} & =\frac{1}{\operatorname{det}}\left[\begin{array}{cc}
d \ell & d R \\
-\left(\frac{\partial^{2} U}{\partial Y^{2}} c(.)^{2}+\phi \frac{\partial^{2} \Phi}{\partial R^{2}}\right) & \frac{\partial^{2} U}{\partial Y^{2}} w c(.) \\
\frac{\partial^{2} U}{\partial Y^{2}} w c(.) & -\left(\frac{\partial^{2} U}{\partial Y^{2}} w^{2}+\psi \frac{\partial^{2} \Psi}{\partial \ell^{2}}\right)
\end{array}\right]
\end{aligned}
$$

while, using Shepard's lemma, and $n=(1-\ell-H)$,

$$
\left[D_{(p, w, I)} F O C\right]=\left[\begin{array}{ccc}
d p & d w & d I \\
\frac{\partial^{2} U}{\partial Y^{2}} w x(.) R & -\frac{\partial^{2} U}{\partial Y^{2}} w n(.)-\frac{\partial U}{\partial Y} & -\frac{\partial^{2} U}{\partial Y^{2}} w \\
\frac{\partial^{2} U}{\partial Y^{2}} c(.) x(.) R-\frac{\partial U}{\partial Y} x(.) & -\frac{\partial^{2} U}{\partial Y^{2}} c(.) n(.)-\frac{\partial U}{\partial Y} h(.) & -\frac{\partial^{2} U}{\partial Y^{2}} c(.)
\end{array}\right]
$$

and

$$
D_{(\psi, \phi, \underline{R})} F O C=\left[\begin{array}{ccc}
d \psi & d \phi & d \underline{R} \\
\frac{\partial \Psi}{\partial \ell} & 0 & 0 \\
0 & \frac{\partial \Phi}{\partial R} & \phi \frac{\partial^{2} \Phi}{\partial R^{2}}
\end{array}\right]
$$


Hence, using $\frac{\partial U}{\partial Y} c()=.\phi \frac{\partial \Phi}{\partial R}$, we obtain

$$
\begin{aligned}
& D_{(p, w, I)}(\ell, R)=\frac{1}{\operatorname{det}} \times
\end{aligned}
$$

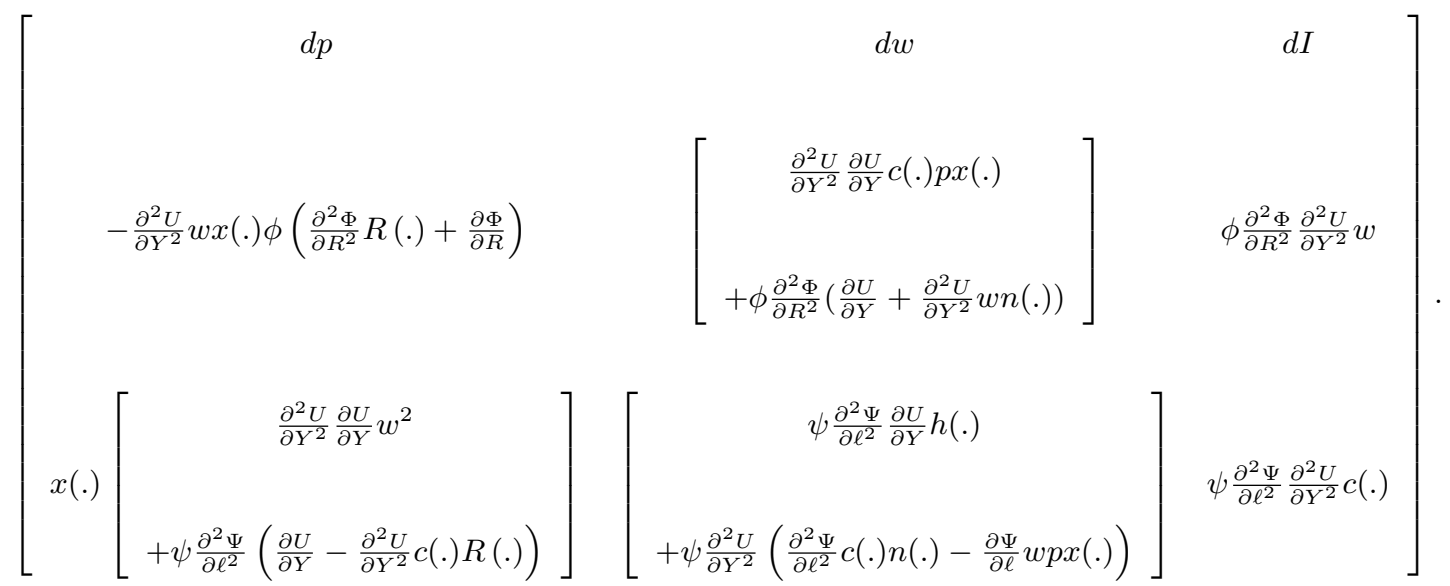

The pattern of the signs of the derivatives is

$$
D_{(p, I, w)}(\ell, R)=\left[\begin{array}{ccc}
d p & d w & d I \\
? & ? & + \\
- & ? & +
\end{array}\right]
$$

where "?" denotes a sign which is not uniquely determined. However, $\frac{\partial \ell}{\partial p}>0$ if and only if $\frac{\partial^{2} \Phi}{\frac{\partial R^{2}}{\partial} R} \frac{\partial}{\partial R}>-1$, as claimed in the text. Similarly, $\frac{\frac{\partial^{2} U}{\partial Y^{2}} w n(.)}{\frac{\partial U}{\partial Y}}>-1$ implies that $\frac{\partial \ell}{\partial w}<0$.

Using the results above, the partial derivatives of the labour supply are

$$
\begin{aligned}
\frac{\partial n}{\partial p} & =-\frac{\partial \ell}{\partial p}-\frac{h(.) R(.)}{p}\left(\frac{\partial R}{\partial p} \frac{p}{R(.)}+\frac{\partial h}{\partial p} \frac{p}{h(.)}\right)<0 \\
\frac{\partial n}{\partial w} & =-\frac{\partial \ell}{\partial w}-\frac{h(.) R(.)}{w}\left(\frac{\partial R}{\partial w} \frac{w}{R(.)}+\frac{\partial h}{\partial w} \frac{w}{h(.)}\right)<0 \\
\frac{\partial n}{\partial I} & =\frac{-1}{\operatorname{det}} \frac{\partial^{2} U}{\partial Y^{2}}\left(\phi \frac{\partial^{2} \Phi}{\partial R^{2}} w+\psi \frac{\partial^{2} \Psi}{\partial \ell^{2}} c(.) h(.)\right)<0 .
\end{aligned}
$$

Evidently, the signs of the first two derivatives depend upon the sign of the derivatives of the demand for leisure and the value of the price elasticities of the demand functions $h($.$) and R($.$) .$ 
Moreover,

$$
D_{(\psi, \phi, \underline{R})}(\ell, R)=\frac{1}{\operatorname{det}}\left[\begin{array}{ccc}
d \psi & d \phi & d \underline{R} \\
-\frac{\partial \Psi}{\partial \ell}\left(\frac{\partial^{2} U}{\partial Y^{2}} c(.)^{2}+\phi \frac{\partial^{2} \Phi}{\partial R^{2}}\right) & \frac{\partial \Phi}{\partial R} \frac{\partial^{2} U}{\partial Y^{2}} w c(.) & \phi \frac{\partial^{2} \Phi}{\partial R^{2}} \frac{\partial^{2} U}{\partial Y^{2}} w c(.) \\
\frac{\partial \Psi}{\partial \ell} \frac{\partial^{2} U}{\partial Y^{2}} w c(.) & -\frac{\partial \Phi}{\partial R}\left(\frac{\partial^{2} U}{\partial Y^{2}} w^{2}+\psi \frac{\partial^{2} \Psi}{\partial \ell^{2}}\right) & -\phi \frac{\partial^{2} \Phi}{\partial R^{2}}\left(\frac{\partial^{2} U}{\partial Y^{2}} w^{2}+\psi \frac{\partial^{2} \Psi}{\partial \ell^{2}}\right)
\end{array}\right] .
$$

The signs of the derivatives are

$$
D_{(\psi, \phi, \underline{R})}(\ell, R)=\left[\begin{array}{ccc}
d \psi & d \phi & d \underline{R} \\
+ & - & + \\
- & + & -
\end{array}\right],
$$

while

$$
\begin{aligned}
\frac{\partial n}{\partial \psi} & =\frac{1}{\operatorname{det}} \frac{\partial \Psi}{\partial \ell}\left(\frac{\partial^{2} U}{\partial Y^{2}} c(.) p x(.)^{2}+\phi \frac{\partial^{2} \Phi}{\partial R^{2}}\right)<0, \\
\frac{\partial n}{\partial \phi} & =\frac{1}{\operatorname{det}} \frac{\partial \Phi}{\partial R}\left(\psi \frac{\partial^{2} \Psi}{\partial \ell^{2}} h(.)-\frac{\partial^{2} U}{\partial Y^{2}} w p x(.)\right), \\
\frac{\partial n}{\partial \underline{R}} & =\frac{1}{\operatorname{det}} \phi \frac{\partial^{2} \Phi}{\partial R^{2}}\left(\psi \frac{\partial^{2} \Psi}{\partial \ell^{2}} h(.)-\frac{\partial^{2} U}{\partial Y^{2}} w p x(.)\right) .
\end{aligned}
$$

as intuitive, since we are considering the effect on the labour supply of an increase in the marginal utility of leisure. The signs of the other two derivatives are not uniquely defined.

\section{B Data sources}

\section{Australia}

The Household, Income and Labour Dynamics in Australia (HILDA) is the raw source for CNEF (Summerfield et al., 2011). HILDA is a household-based survey starting in 2001 and data are collected every two years. HILDA reports information on economic performances, labour market dynamics and family dynamics for about 16,800 individuals (both natives and migrants). An individual is a worker in the household service sector if he/she is employed in one of the following ISIC 3.1 sector: hotels and restaurants (55), health and social work (85), sewage and refuse disposal, sanitation and similar activities (90), activities of membership organizations n.e.c. (91), recreational, cultural and sporting activities (92), other service activities (93), activities of private households as employers of domestic staff (95). In the HILDA sample there are no workers employed in the following service sectors: undifferentiated goods/service-producing activities of private households for own use (96 and 97).

HILDA reports the highest level of education (with respect to high school) of all individuals in the household (e.g., less than high school, high school, more than high school). To construct our instrumental variable, we employ census 
database from 1991 (Australian Bureau of Statistics, 1991). We define as region of destination the state of residence, so that data are aggregated according to this criterion. HILDA defines the area of residence as the major city or state; we allocate individuals living in major cities to the corresponding state.

\section{Germany}

The German Socio-Economic Panel (SOEP) is the raw source for CNEF and it is collected on a yearly basis by the German Institute of Economic Research (DIW Berlin) since1984 (Wagner et al., 2012). SOEP provides a representative collection of biographical information for the entire German population. Similarly to HILDA, SOEP follows participants over time and each respondent answers the biographical questions only once (retrospectively). SOEP has around 34,000 entries each year, for both natives and migrants. Precisely, a migrant is a foreign born individual which immigrates after 1948. An individual is a worker in the household service sector if he/she is employed in one of the following NACE rev1.1 sector: hotel and restaurant (55), health and social work (85), private households with employed persons (90), activities of membership organizations n.e.c. (91), recreational, cultural and sporting activities (92), other service activities (93). Finally, 1991 SOEP survey is used to construct the regional distribution of migrants by country of origin and region of destination. Region of residence is defined in SOEP/CNEF as state, i.e., Länder. Berlin is reported in SOEP as Berlin West or East, whereas the states of Rhineland-Palatinate and Saarland are reported as one state.

\section{Switzerland}

The Swiss Household Panel (SHP) is the raw source for CNEF. SHP is a stratified random sample of private households whose members represent the non-institutional population resident in Switzerland. The survey questionnaires are designed to collect both quantitative data (e.g., wages or age) and qualitative data (e.g., satisfaction with various life domains) for about 10,000 individuals. An individual is a worker in the household service sector if he/she is employed in one of the following NOGA 2002 sector used by Swiss statical offices. ${ }^{56}$ : hotels and restaurants, (8), health and social work (14), other community, social and personal service activities (15).

SHP reports the highest level of education (with respect to high school ) of all individuals in the household. To construct our instrumental variable we employ census data from 1990 (Swiss Federal Statistical Office), in order to construct the distribution of migrants by nationality of origin and region of destination. We define as region of destination/residence the Swiss Canton in which the household was living at the time of the interview. ${ }^{57}$

\section{United Kingdom}

The British Household Panel Survey (BHPS) is the raw source for CNEF (Brice et al., 2010). BHPS does not provide information about migrants. To calculate the immigrants' labour supply at regional level, we employ quarterly labour force surveys (LFS). LFS are collected by the Office for National Statistics (ONS) on a rotating quarterly panel, and the

\footnotetext{
${ }^{56}$ NOGA is the General Classification of Economic Activities the 2008 version is modelled on NACE rev2.

${ }^{57}$ In our sample we consider 24 Swiss Canton instead of 26: we aggregate Appenzell Inner-Rhodes and Appenzell Outer-Rhodes. URI is dropped because of too few observations.
} 
annual LFS dataset is defined according to Economic and Social Data Services criteria. LFS reports the country of birth of individuals for both 2001, 2003, and 2005. Given the definition of our main explanatory variable (Eq.6), we calculate the domestic labour supply using LFS to have a coherent data source for both labour market aggregates. To define labour supply in household service sector, we consider the SIC 92 (at two digit) classification. We include among household services: hotel and restaurant (55), education (80), health and social works (85), sanitation disposal etc. (90), activity of membership organisations (91), recreational activity (92), other services activities (93), and private household with employed persons (95). Finally, labour supply data are matched at regional-year level with the micro-level data from CNEF-BHPS. To define a concordance between regional classifications in BHPS and LFS, we classify regions following NUTS 2 or NUTS 1 categories (see TableC.4). Data on the distribution of migrants by country of origins and region of destinations are obtained from 1991 census (Office for National Statistics, ONS). We exclude from our sample Scotland and North of Ireland: we have no information about migrants by country of origins for these two regions in the census year.

Concerning the educational level of individuals, both BHPS and LFS report "the highest educational qualification". To guarantee that the UK classification is coherent with the educational attainments reported in other CNEF surveys, we classify individuals skilled or unskilled by following the same approach of Dustmann and Theodoropoulos (2010) and Manacorda et al. (2012). Skilled workers declare a bachelor or higher degree as the highest educational attainment, while unskilled workers report high school, or lower degree. Data on the distribution of migrants by origin and destination are obtained from 1991 census (Office for National Statistics, ONS). Given census data, we exclude from our sample Scotland and North of Ireland: we have no information about migrants by country of origin for these two regions, for census year (and North of Ireland is not present in CNEF).

\section{USA}

The Panel Study of Income Dynamics (PSID) is the raw source for CNEF. As BHPS, also PSID does not include information on foreign born individuals in the survey. Nonetheless, from 2001 it is possible to identify people with Hispanic origin using sampling weights. We eliminate these individuals from estimation sample to avoid cultural bias (Furtado and Hock, 2010). Then, we remain with 16,600 observations per year. We measure the labour supply of migrants in year 2001, 2003, and 2005 with the Annual Community Surveys (ACS). Data are available through the Integrated Public Use Microdata Series (Ruggles et al., 2010). ACS reports the country of birth of individuals. To define the labour supply in the household service sector, we consider the industrial classification provided by ACS. The census term "industry" currently refers to work setting and economic sector. We take into account the following sectors: health and personal care services, recreational activity, other services activities. Sectors range from 7970 to 8470 and from 8560 to 9290 (according to ACS classification). Given the definition of our main explanatory variable (Eq.6), we calculate the domestic labour supply using ACS to have a coherent data source for both labour market aggregates. Labour supply data are matched at regional-year level with the information in CNEF-PSID database. Regions of residence are the 51 national states. In order to identify both the labour supply of unskilled migrants, and the skill levels of native women, we use information on educational attainments. Both PSID and ACS reports the highest level of education (with respect 
to high school ) of all individuals in the household. Similarly to other countries, an unskilled person is an individual with high school, or less than high school, degree. Finally, data for instruments are collected from 1990 USA Census (Ruggles et al., 2010).

\section{Additional Tables}

Table C.1: Data sources ${ }^{\ddagger}$

\begin{tabular}{l|l|l|l|l}
\hline Country & Natives labour supply & Migrants labour supply & Total labour force & Instrument \\
\hline Australia & HILDA (CNEF) & HILDA (CNEF) & HILDA (CNEF) & Census 1991 \\
Germany & SOEP (CNEF) & SOEP (CNEF) & SOEP (CNEF) & SOEP 1990 \\
United Kingdom & BHPS (CNEF) & LFS & LFS & Census 1991 \\
Switzerland & SHP (CNEF) & SHP (CNEF) & SHP (CNEF) & Census 1991 \\
USA & PSID (CNEF) & ACS & ACS & Census 1990 \\
\hline
\end{tabular}

$\ddagger$ Instruments refer to migrants by country of origin and region of destination in the census year. The other variables refer to year 2001, 2003, 2005.

Table C.2: Native women, participation and hours per week by skill ${ }^{\ddagger}$

\begin{tabular}{lccc|lrcc}
\hline \hline & Participation & \multicolumn{3}{c}{} & & Hours per week & \\
& Unsk & Skill & Diff. I & & Unsk & Skill & Diff. II \\
\hline All(mean) & 0.760 & 0.853 & -0.093 & All(mean) & 29.90 & 32.88 & -2.98 \\
All(obs.) & 18307 & 8636 & $(* * *)$ & All(obs.) & 13897 & 7356 & $(* *)$ \\
\hline AUS(mean) & 0.656 & 0.848 & -0.192 & AUS(mean) & 29.12 & 32.76 & -3.64 \\
AUS(obs.) & 2771 & 1759 & $(* * *)$ & AUS(obs.) & 1815 & 1490 & $(* * *)$ \\
\hline CH(mean) & 0.726 & 0.849 & -0.123 & CH(mean) & 26.59 & 31.16 & -4.57 \\
CH(obs.) & 2409 & 762 & $(* * *)$ & CH(obs.) & 1746 & 643 & $(* *)$ \\
\hline GER(mean) & 0.762 & 0.840 & -0.078 & GER(mean) & 30.19 & 32.66 & -2.47 \\
GER(obs.) & 6946 & 2056 & $(* * *)$ & GER(obs.) & 5293 & 1727 & $(* * *)$ \\
\hline UK(mean) & 0.812 & 0.869 & -0.057 & UK(mean) & 29.82 & 34.33 & -4.51 \\
UK(obs.) & 3319 & 816 & $(* * *)$ & UK(obs.) & 2694 & 709 & $(* * *)$ \\
\hline USA(mean) & 0.822 & 0.859 & -0.038 & USA(mean) & 32.43 & 33.10 & -0.68 \\
USA(obs.) & 2862 & 3243 & $(* * *)$ & USA(obs.) & 2349 & 2787 & $(* * *)$ \\
\hline
\end{tabular}

$\ddagger$ Unsk: unskilled women. Skilled: skilled women. Mean in parenthesis stays for weighted sample mean. Obs. in parenthesis stays for sample observations. Hours per week includes only woman who report a positive wage. Diff. I reports the difference of average participation rate between unskilled and skilled women. Diff. II reports the difference of average labour supply (hours per week) between unskilled and skilled women. We report the significance level for the test of mean differences (t-test) between unskilled and skilled women: $* * *$ is $0.01>$ p-value.

Table C.3: Unskilled migrants in services, country averages ${ }^{\ddagger}$

\begin{tabular}{|c|c|c|c|c|c|c|c|c|}
\hline & \multicolumn{4}{|c|}{$\frac{\text { UnskMigrServ }}{\text { UnskMigrServ+UnskNatServ }}$} & \multicolumn{4}{|c|}{$\frac{\text { UnskMigrServ }}{\text { UnskNatServ }}$} \\
\hline & 2001 & 2003 & 2005 & Total & 2001 & 2003 & 2005 & Total \\
\hline Australia & 0.153 & 0.154 & 0.135 & 0.148 & 0.183 & 0.189 & 0.160 & 0.177 \\
\hline Switzerland & 0.188 & 0.211 & 0.212 & 0.203 & 0.307 & 0.360 & 0.326 & 0.329 \\
\hline Germany & 0.075 & 0.078 & 0.065 & 0.073 & 0.086 & 0.089 & 0.072 & 0.083 \\
\hline United Kingdom & 0.080 & 0.094 & 0.056 & 0.077 & 0.102 & 0.121 & 0.065 & 0.096 \\
\hline USA & 0.134 & 0.133 & 0.140 & 0.135 & 0.183 & 0.176 & 0.189 & 0.183 \\
\hline Total & 0.115 & 0.118 & 0.110 & 0.114 & 0.153 & 0.157 & 0.144 & 0.151 \\
\hline
\end{tabular}

¥ Averages by countries. $\frac{U n s k M i g r \text { Serv }}{\text { UnskMigrSer+UnskNatServ }}$ is the ratio of unskilled migrants in services to total unskilled labour force in services. $\frac{\text { UnskMigrServ }}{\text { UnskNatServ }}$ is the ratio of unskilled migrants in services to unskilled natives in services. 
Table C.4: Share of unskilled migrant in services to total labour force by country/region/year (in percentage points) $)^{\ddagger}$.

\begin{tabular}{|c|c|c|c|c|c|c|c|}
\hline \multirow[t]{2}{*}{ Regions } & 2001 & 2003 & 2005 & Regions & 2001 & 2003 & 2005 \\
\hline & \multicolumn{3}{|c|}{ Switzerland } & & \multicolumn{3}{|c|}{ USA } \\
\hline Argovia & 0.266 & 0.547 & 1.272 & Alabama & 0.195 & 0.548 & 0.368 \\
\hline Appenzell Rhodes & 5.519 & 7.992 & 0.000 & Alaska & 1.116 & 1.477 & 1.181 \\
\hline Berne & 0.000 & 0.502 & 0.962 & Arizona & 2.478 & 2.902 & 3.038 \\
\hline Basle-Country & 3.768 & 5.013 & 3.525 & Arkansas & 0.478 & 0.493 & 0.473 \\
\hline Basle-Town & 5.060 & 1.669 & 1.568 & California & 3.808 & 4.091 & 4.311 \\
\hline Fribourg & 0.572 & 0.864 & 1.789 & Colorado & 1.412 & 1.774 & 2.200 \\
\hline Geneva & 3.806 & 3.962 & 5.631 & Connecticut & 1.872 & 2.397 & 2.397 \\
\hline Glarus & 7.095 & 0.000 & 0.000 & Delaware & 1.069 & 1.004 & 1.452 \\
\hline Grisons & 0.000 & 0.000 & 0.000 & District of Columbia & 1.686 & 1.070 & 0.988 \\
\hline Jura & 0.000 & 0.000 & 0.000 & Florida & 2.869 & 3.245 & 3.240 \\
\hline Lucerne & 0.000 & 0.000 & 1.156 & Georgia & 0.815 & 1.374 & 1.307 \\
\hline Neuchatel & 1.815 & 2.081 & 4.247 & Hawaii & 4.802 & 3.739 & 4.300 \\
\hline Nidwalden & 0.000 & 0.000 & 0.000 & Idaho & 0.534 & 0.878 & 1.004 \\
\hline Obwalden & 9.777 & 0.000 & 0.000 & Illinois & 2.007 & 2.019 & 2.171 \\
\hline St. Gall & 1.173 & 1.028 & 0.802 & Indiana & 0.557 & 0.397 & 0.749 \\
\hline Schaffhausen & 7.46 & 14.08 & 11.91 & Iowa & 0.319 & 0.450 & 0.371 \\
\hline Solothurn & 2.507 & 1.725 & 1.658 & Kansas & 0.664 & 0.811 & 1.012 \\
\hline Schwyz & 3.334 & 4.215 & 0.000 & Kentucky & 0.208 & 0.297 & 0.364 \\
\hline Thurgovia & 3.792 & 6.657 & 0.000 & Louisiana & 0.418 & 0.439 & 0.409 \\
\hline Ticino & 0.982 & 4.176 & 3.451 & Maine & 0.358 & 0.579 & 0.610 \\
\hline Vaud & 2.831 & 3.018 & 3.979 & Maryland & 1.253 & 1.028 & 1.180 \\
\hline Valais & 0.000 & 0.000 & 4.242 & Massachusetts & 2.311 & 2.458 & 2.709 \\
\hline Zug & 0.000 & 0.000 & 0.000 & Michigan & 0.595 & 0.607 & 0.658 \\
\hline Zurich & 0.982 & 1.393 & 1.953 & Mississippi & 0.212 & 0.536 & 0.380 \\
\hline \multirow{3}{*}{ Total } & 1.566 & 1.901 & 2.129 & Missouri & 0.432 & 0.640 & 0.772 \\
\hline & & & & Nebraska & 0.566 & 0.925 & 1.005 \\
\hline & & UK & & Nevada & 5.636 & 5.829 & 5.609 \\
\hline East Anglia & 0.754 & 0.909 & 0.844 & New Hampshire & 0.519 & 0.482 & 0.715 \\
\hline East Midlands & 0.511 & 0.743 & 0.672 & New Jersey & 2.700 & 2.658 & 3.051 \\
\hline Great Manchester & 0.923 & 0.904 & 1.372 & New Mexico & 1.224 & 2.496 & 2.146 \\
\hline Inner London & 4.502 & 4.759 & 4.191 & New York & 3.718 & 3.829 & 3.944 \\
\hline Mersey Side & 0.509 & 0.532 & 0.691 & North Carolina & 0.577 & 1.150 & 0.965 \\
\hline Outer London & 2.872 & 3.393 & 3.242 & North Dakota & 0.327 & 0.268 & 0.207 \\
\hline Rest of North & 0.369 & 0.223 & 0.670 & Ohio & 0.248 & 0.355 & 0.453 \\
\hline Rest of South East & 0.678 & 0.586 & 0.556 & Oklahoma & 0.833 & 1.066 & 1.025 \\
\hline Rest of West Midlands & 0.956 & 1.219 & 1.374 & Oregon & 1.249 & 1.686 & 1.452 \\
\hline Rest of Yorkshire \& Humbe & 0.458 & 0.558 & 0.421 & Pennsylvania & 0.693 & 0.745 & 0.988 \\
\hline Rest of north west & 0.103 & 0.603 & 0.413 & Rhode Island & 1.651 & 1.581 & 1.748 \\
\hline South East & 0.545 & 0.871 & 1.024 & South Carolina & 0.505 & 0.742 & 0.706 \\
\hline South Yorkshire & 0.371 & 0.515 & 0.838 & South Dakota & 0.299 & 0.435 & 0.241 \\
\hline Tyne and Wear & 0.160 & 0.575 & 0.648 & Tennessee & 0.358 & 0.533 & 0.577 \\
\hline Wales & 0.435 & 0.612 & 0.507 & Texas & 2.586 & 3.196 & 2.987 \\
\hline West Midlands County & 1.099 & 1.138 & 1.510 & Utah & 1.308 & 1.400 & 1.251 \\
\hline West Yorkshire & 0.544 & 0.739 & 0.936 & Vermont & 0.232 & 0.672 & 0.248 \\
\hline \multirow[t]{3}{*}{ Total } & 0.787 & 0.966 & 1.001 & Virginia & 0.859 & 0.846 & 1.150 \\
\hline & & & & Washington & 1.367 & 1.593 & 1.636 \\
\hline & \multicolumn{3}{|c|}{ Germany } & West Virginia & 0.112 & 0.270 & 0.239 \\
\hline Baden-Wuttemberg & 1.338 & 1.272 & 1.314 & Wisconsin & 0.662 & 0.720 & 0.750 \\
\hline Bavaria & 0.764 & 0.497 & 0.455 & Wyoming & 0.677 & 0.712 & 0.624 \\
\hline Berlin (East) & 0.000 & 0.000 & 0.000 & Total & 1.316 & 1.516 & 1.571 \\
\hline Berlin (West) & 0.000 & 0.921 & 0.367 & & & & \\
\hline Brandenburg & 0.000 & 0.000 & 0.000 & & \multicolumn{3}{|c|}{ Australia } \\
\hline Bremen & 2.510 & 1.137 & 0.000 & $\mathrm{ACT}$ & 1.721 & 1.856 & 0.883 \\
\hline Hamburg & 0.000 & 0.000 & 0.447 & New South Wales & 1.797 & 2.238 & 2.278 \\
\hline Hessen & 1.344 & 1.438 & 0.595 & Northern Terr. & 0.000 & 2.453 & 3.798 \\
\hline Lower Saxony & 0.351 & 0.566 & 0.627 & Queensland & 1.317 & 1.460 & 1.471 \\
\hline Mecklenburg-V. & 0.046 & 0.000 & 0.000 & South Australia & 1.942 & 2.087 & 1.258 \\
\hline N.Rhine-Westphalia & 0.694 & 0.621 & 0.612 & Tasmania & 0.220 & 0.228 & 0.196 \\
\hline Rhineland \& Saarland & 0.855 & 1.636 & 1.343 & Victoria & 1.726 & 1.130 & 0.901 \\
\hline Saxony & 0.112 & 0.100 & 0.102 & West Australia & 1.881 & 2.258 & 1.372 \\
\hline Saxony-Anhalt & 0.000 & 0.000 & 0.000 & Total & 1.637 & 1.717 & 1.514 \\
\hline Schleswig-Hols. & 0.330 & 0.642 & 0.512 & & & & \\
\hline Thueringen & 0.000 & 0.000 & 0.000 & & & & \\
\hline Total & 0.605 & 0.644 & 0.553 & & & & \\
\hline
\end{tabular}

$¥$ Immigration intensity is the ratio of unskilled migrants in household services to total labour force, in percentage point. See Eq. 6. 
Table C.5: Migrants and instrument, descriptive statistics. ${ }^{\ddagger}$

\begin{tabular}{l|ccccc|cccccc}
\hline \hline & \multicolumn{4}{|c|}{ Migr. service (Eq.6) } & \multicolumn{5}{c}{ Instrument (Eq.8) } \\
& Mean & S.D. & Min & Max & Iqr & Mean & S.D. & Min & Max & Iqr \\
\hline \multirow{3}{*}{ Australia } & & & & & & & & & & & \\
Switzerland & 0.015 & 0.009 & 0.000 & 0.038 & 0.010 & 0.010 & 0.002 & 0.005 & 0.015 & 0.002 \\
Germany & 0.023 & 0.029 & 0.000 & 0.141 & 0.038 & 0.014 & 0.006 & 0.005 & 0.040 & 0.007 \\
United Kingdom & 0.006 & 0.007 & 0.000 & 0.025 & 0.011 & 0.004 & 0.004 & 0.000 & 0.014 & 0.005 \\
USA & 0.010 & 0.012 & 0.001 & 0.063 & 0.007 & 0.007 & 0.009 & 0.000 & 0.042 & 0.005 \\
Total & 0.013 & 0.012 & 0.001 & 0.058 & 0.012 & 0.007 & 0.008 & 0.001 & 0.048 & 0.008 \\
\hline
\end{tabular}

$\ddagger$ Source: our calculation from CNEF, ACS, LFS and Census data in 1990 or 1991. Mean: region year average. S.D.: region year standard deviation. Min: minimum value region year, Max: maximum value region year. Iqr: interquantile range region year.

Table C.6: Data description ${ }^{\ddagger}$

\begin{tabular}{|c|c|c|}
\hline Code & Description & Additional Notes \\
\hline Part & $\begin{array}{l}\text { Part is a binary variable defined for individual } i \text {, in region } \\
r \text {, in country } c \text { at time } t \text {. It defines employment status. It } \\
\text { takes value one if a woman had positive wage and worked } \\
\text { at least } 52 \text { hours in the previous year. Otherwise, the } \\
\text { variable Part } \text { irct }_{\text {takes value zero. }}\end{array}$ & $\begin{array}{l}\text { In addition, } \text { Part }_{\text {irct }} \text { is also defined for full time and part } \\
\text { time employment level. Full time: Part }(\text { full })_{\text {irct }} \text { takes } \\
\text { value one if a woman had positive wages, and worked at } \\
\text { least } 1,820 \text { hours last year ( } 35 \text { hours per week on } \\
\text { average); if the woman is not employed the dummy is } \\
\text { equal to zero. Part time: the variable Part }(\text { part })_{\text {irct }} \\
\text { takes value one if a woman had positive wages, and } \\
\text { worked at least } 52 \text { hours but less than } 1,820 \text { hours last } \\
\text { year; if not employed the dummy takes value zero. }\end{array}$ \\
\hline $\operatorname{Pr}($ Hour $\geq \mathrm{x})$ & $\begin{array}{l}\text { It is a dummy variable that takes value one if an } \\
\text { individual } i \text {, in region } r \text {, in country } c \text { at time } t \text { works } \\
\text { more than } \mathrm{x} \text { hours per week. }\end{array}$ & It is defined only for employed persons. \\
\hline $\operatorname{Pr}\left(\right.$ Hours $\geq \mathrm{x}^{t h}$ pct $)$ & $\begin{array}{l}\text { It is a dummy variable that takes value one if the weekly } \\
\text { labour supply of a woman is higher than the } \mathrm{x}^{t} h \\
\text { percentile of weekly hour distribution (by country and } \\
\text { skill level): for example, given a distribution of working } \\
\text { hours by country and skill level, } \operatorname{Pr}\left(\text { Hours } \geq 90^{t h} \text { pct) is a }\right. \\
\text { dummy equal to one if an employed woman supplies more } \\
\text { hours per week than } 90^{t} h \text { percentile. }\end{array}$ & It is defined only for employed persons. \\
\hline Migr. Services & $\begin{array}{l}\text { Migr. Services is the immigration ratio calculated at } \\
\text { regional/year level (intensity). It is defined as the ratio of } \\
\text { unskilled migrants employed in services to total labour } \\
\text { force. It ranges from } 0 \text { to } 1 \text {. Look equation } 6 \text {. }\end{array}$ & $\begin{array}{l}\text { Total labour force is the total amount of employed, both } \\
\text { natives and domestic. }\end{array}$ \\
\hline Instr $r_{r c t}$ & $\begin{array}{l}\text { Instr } r_{r t} \text { is the instrumental variable for migrants' labour } \\
\text { supply in services at regional level. It is defined as the } \\
\text { ratio of unskilled migrant predicted value to regional } \\
\text { population in year } 1990 \text { (Card, 2001). Look equation } 7 \text {. }\end{array}$ & $\begin{array}{l}\text { We consider in Census data, only countries of origin that } \\
\text { are reported in CNEF, LFS, and ACS. For each country } \\
\text { of destination, we take into account the } 1990 \text { distribution } \\
\text { of immigrants by country of origin, and region of } \\
\text { destination. }\end{array}$ \\
\hline Age, Age $^{2}$ & $\begin{array}{l}\text { Age of the individual at surveys year, and its squared } \\
\text { term. }\end{array}$ & \\
\hline $\begin{array}{l}\text { Child(01), Child(24), } \\
\text { Child(57) }\end{array}$ & $\begin{array}{l}\text { These are four dummy variables that take value one if a } \\
\text { woman has one or more children with age } 0-1,2-4 \text {, and } \\
5-7 \text { respectively. }\end{array}$ & \\
\hline Skilled & $\begin{array}{l}\text { It is a dummy variable equal to one if an individual } \\
\text { (migrants or native) has a bachelor or higher degree, } \\
\text { otherwise it takes value zero }\end{array}$ & $\begin{array}{l}\text { The highest level of education (with respect to high } \\
\text { school) }\end{array}$ \\
\hline Marit. Status & $\begin{array}{l}\text { It is a dummy variable that takes value one if a woman is } \\
\text { married or cohabitant, otherwise it takes value zero. }\end{array}$ & Legally cohabitant with a partner \\
\hline $\begin{array}{l}\text { HH Income, HH } \\
\text { Income }^{2}\end{array}$ & $\begin{array}{l}\text { It is the gross household income minus woman gross } \\
\text { earnings, in US dollar PPP } 2000 \text { (in logs). HH Income }{ }^{2} \text { is } \\
\text { squared term. }\end{array}$ & \\
\hline Num. Old & is the number of household members with age above 65 . & \\
\hline
\end{tabular}


Table C.7: Intensive margin of labour supply - weekly labour supply ${ }^{\ddagger}$.

\begin{tabular}{|c|c|c|c|c|c|c|c|c|}
\hline & $\begin{array}{c}(1) \\
\text { OLS } \\
\text { All } \\
\end{array}$ & $\begin{array}{l}(2) \\
\text { IV } \\
\text { All } \\
\end{array}$ & $\begin{array}{c}(3) \\
\text { OLS } \\
\text { Skilled }\end{array}$ & $\begin{array}{c}(4) \\
\text { IV } \\
\text { Skilled } \\
\end{array}$ & $\begin{array}{c}(5) \\
\text { OLS } \\
\text { Unsk. }\end{array}$ & $\begin{array}{c}(6) \\
\text { IV } \\
\text { Unsk. }\end{array}$ & $\begin{array}{c}(7) \\
\text { OLS } \\
\text { Unsk NS }\end{array}$ & $\begin{array}{c}(8) \\
\text { IV } \\
\text { Unsk. NS } \\
\end{array}$ \\
\hline Panel $A$ & & & \multicolumn{4}{|c|}{$\operatorname{Pr}($ Hours $\geq 20)$} & & \\
\hline Migr. services $_{r t}$ & $\begin{array}{c}1.073 \\
{[0.790]}\end{array}$ & $\begin{array}{c}6.731 \\
{[5.757]}\end{array}$ & $\begin{array}{c}4.924^{* * *} \\
{[1.867]}\end{array}$ & $\begin{array}{c}4.163 \\
{[5.679]}\end{array}$ & $\begin{array}{l}-0.536 \\
{[0.981]}\end{array}$ & $\begin{array}{c}7.241 \\
{[6.769]}\end{array}$ & $\begin{array}{c}8.055 \\
{[6.693]}\end{array}$ & $\begin{array}{l}10.720 \\
{[8.633]}\end{array}$ \\
\hline Obs. & 18,334 & 18,334 & 6,177 & 6,177 & 12,157 & 12,157 & 14,960 & 8,783 \\
\hline $\mathrm{R}^{2}$ & 0.190 & 0.189 & 0.193 & 0.193 & 0.196 & 0.192 & 0.190 & 0.196 \\
\hline F-Stat & . & 15.74 & . & 22.02 & . & 13.14 & 17.12 & 14.24 \\
\hline Control & yes & yes & yes & yes & yes & yes & yes & yes \\
\hline Region \& year FE & yes & yes & yes & yes & yes & yes & yes & yes \\
\hline Panel B & & & \multicolumn{4}{|c|}{$\operatorname{Pr}($ Hours $\geq 30)$} & & \\
\hline Migr. services $r t$ & $\begin{array}{l}-0.014 \\
{[1.072]}\end{array}$ & $\begin{array}{l}7.852^{*} \\
{[4.261]}\end{array}$ & $\begin{array}{c}1.567 \\
{[2.101]}\end{array}$ & $\begin{array}{l}13.037 \\
{[8.063]}\end{array}$ & $\begin{array}{l}-0.841 \\
{[1.225]}\end{array}$ & $\begin{array}{c}4.396 \\
{[4.390]}\end{array}$ & $\begin{array}{c}6.909 \\
{[4.309]}\end{array}$ & $\begin{array}{c}3.461 \\
{[4.928]}\end{array}$ \\
\hline Obs. & 18,334 & 18,334 & 6,177 & 6,177 & 12,157 & 12,157 & 14,960 & 8,783 \\
\hline $\mathrm{R}^{2}$ & 0.211 & 0.209 & 0.204 & 0.199 & 0.225 & 0.224 & 0.212 & 0.238 \\
\hline F-Stat & . & 15.74 & . & 22.02 & . & 13.14 & 17.12 & 14.24 \\
\hline Control & yes & yes & yes & yes & yes & yes & yes & yes \\
\hline Region \& year FE & yes & yes & yes & yes & yes & yes & yes & yes \\
\hline Panel $C$ & & & \multicolumn{4}{|c|}{$\operatorname{Pr}($ Hours $\geq 40)$} & & \\
\hline Migr. services $_{r t}$ & $\begin{array}{l}-0.471 \\
{[1.007]}\end{array}$ & $\begin{array}{c}5.381 \\
{[3.955]}\end{array}$ & $\begin{array}{l}-0.235 \\
{[2.362]}\end{array}$ & $\begin{array}{c}6.282 \\
{[6.298]}\end{array}$ & $\begin{array}{l}-0.884 \\
{[1.142]}\end{array}$ & $\begin{array}{c}5.260 \\
{[4.270]}\end{array}$ & $\begin{array}{l}8.786^{*} \\
{[4.992]}\end{array}$ & $\begin{array}{c}10.096^{*} \\
{[5.562]}\end{array}$ \\
\hline Obs. & 18,334 & 18,334 & 6,177 & 6,177 & 12,157 & 12,157 & 14,960 & 8,783 \\
\hline $\mathrm{R}^{2}$ & 0.101 & 0.099 & 0.146 & 0.144 & 0.084 & 0.082 & 0.105 & 0.088 \\
\hline F-Stat & . & 15.74 & . & 22.02 & . & 13.14 & 17.12 & 14.24 \\
\hline Control & yes & yes & yes & yes & yes & yes & yes & yes \\
\hline Region \& year FE & yes & yes & yes & yes & yes & yes & yes & yes \\
\hline Panel D & & & \multicolumn{4}{|c|}{$\operatorname{Pr}($ Hours $\geq 50)$} & & \\
\hline Migr. services $r t$ & $\begin{array}{c}0.443 \\
{[0.470]}\end{array}$ & $\begin{array}{c}3.527^{* * *} \\
{[1.227]}\end{array}$ & $\begin{array}{c}0.210 \\
{[1.282]}\end{array}$ & $\begin{array}{c}5.266^{* * *} \\
{[1.748]}\end{array}$ & $\begin{array}{c}0.608 \\
{[0.492]}\end{array}$ & $\begin{array}{c}2.069 \\
{[1.695]}\end{array}$ & $\begin{array}{c}3.558^{* *} \\
{[1.480]}\end{array}$ & $\begin{array}{c}1.341 \\
{[2.518]}\end{array}$ \\
\hline Obs. & 18,334 & 18,334 & 6,177 & 6,177 & 12,157 & 12,157 & 14,960 & 8,783 \\
\hline $\mathrm{R}^{2}$ & 0.032 & 0.030 & 0.079 & 0.075 & 0.023 & 0.023 & 0.035 & 0.028 \\
\hline F-Stat & . & 15.74 & . & 22.02 & . & 13.14 & 17.12 & 14.24 \\
\hline Control & yes & yes & yes & yes & yes & yes & yes & yes \\
\hline Region \& year FE & yes & yes & yes & yes & yes & yes & yes & yes \\
\hline \multicolumn{9}{|c|}{$\begin{array}{l}\ddagger \text { Linear probability model. Each column represents a different regression for employed native women. Table } \\
\text { reports only the coefficient of Migr. service (Eq. } 6 \text {. Significance level: } * 0.10>\text { p-value, } * * 0.05>\text { p-value, } * * * \\
0.01>\text { p-value. Standard errors are clustered at regional X year level, and are reported in squared brackets. } \\
\text { F-Stat is the Kleibergen-Paap } r k \text { statistic. All estimations include the following controls: age, age squared, } \\
\text { marital status, dummy for children with age } 0-12-45-7 \text {, household gross earnings minus women earnings and its } \\
\text { squared term, number of elderly people in the household. Columns } 1 \text { and } 2 \text { include an indicator for individual } \\
\text { educational level. Regional controls include unemployment rate, and female participation rate. All: sample of } \\
\text { all natives women. Skilled: sample of natives skilled women. Unsk: sample of natives unskilled women. Unsk } \\
\text { NS: sample of natives unskilled women not employed in household service sectors. }\end{array}$} \\
\hline
\end{tabular}

